\title{
Ophthalmologica
}

Ophthalmologica 2012;227:115-131

DOI: $\underline{10.1159 / 000331418}$
Received: July 29, 2011

Accepted: July 29, 2011

Published online: September 22, 2011

\section{Oxygen Sensing in Retinal Health and Disease}

\author{
Clemens A.K. Lange ${ }^{a, b} \quad$ James W.B. Bainbridge ${ }^{a}$ \\ ${ }^{a}$ NIHR Biomedical Research Centre for Ophthalmology at Moorfields Eye Hospital and UCL Institute of

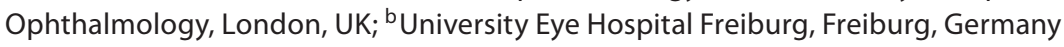

Key Words

Oxygen sensing $\cdot$ Retina

\begin{abstract}
The retina has a uniquely high metabolic demand for oxygen that is normally met by a highly efficient vascular supply. Oxygen plays an essential role in oxidative phosphorylation as an electron acceptor in the mitochondrial respiratory chain in the synthesis of adenosine triphosphate required to support the metabolic demand, including that of the visual cycle. Maintenance of normal retinal function depends on a continuous supply of oxygen and on the capability to detect and respond rapidly to local oxygen deficiency (hypoxia). The functional reserve of oxygen is small and retinal hypoxia can cause neuroretinal dysfunction and degeneration that lead directly to vision loss. Local oxygen sensing mechanisms control adaptive responses that can help protect against ischaemic injury. In the retina, powerful oxygen sensing mechanisms rapidly detect alterations in intracellular oxygen tension and respond with adaptive changes that redress the balance between oxygen supply and demand. These responses include rapid changes in blood flow, protective metabolic adaptations and angiogenesis. In the eye, however, the angiogenic response to hypoxia is typically associated with oedema, haemorrhage and fibrosis that can exacerbate hypoxic neuroretinal injury, causing severe vision loss. This aberrant response is the target of novel thera-
\end{abstract}

pies including inhibitors of vascular endothelial growth factor. However, non-specific angiostatic agents fail to consider appropriate beneficial adaptive responses to hypoxia, and risk compromising neuroprotective mechanisms. In this review, we discuss the current understanding of retinal oxygenation and oxygen sensing in health and disease, focussing on the central role of hypoxia-inducible transcription factors, and suggest that therapeutic strategies may be improved by considering more targeted interventions.

Copyright $\odot 2011$ S. Karger AG, Basel

\section{Retinal Oxygenation}

The vascular supply to the retina uniquely comprises 2 independent and physiologically different circulations (fig. 1). The inner retina in humans is nourished by superficial and deep vascular plexi derived from the central retinal artery, and the outer retina is supplied by choroidal circulation deep to the retinal pigment epithelium (RPE) and its ('Bruch's') basement membrane [1]. The retinal vasculature has a relatively low blood flow and a high oxygen extraction ratio $(8 \mathrm{ml}$ oxygen per $100 \mathrm{ml})$ compared to other tissues, resulting in a high arteriovenous oxygen saturation difference and a low venous oxygen tension $[2,3]$. In contrast to the choroid, blood flow in the inner retinal vasculature is autoregulated; both retinal vascular endothelial cells and non-endothelial cells re-

\section{KARGER}

Fax +4161306 1234

E-Mail karger@karger.ch

www.karger.com
(C) 2011 S. Karger AG, Basel

0030-3755/12/2273-0115\$38.00/0

Accessible online at:

www.karger.com/oph
Prof. James Bainbridge, MA, PhD, FRCOphth

UCL Institute of Ophthalmology

11-43 Bath Street

London EC1V 9EL (UK)

Tel. +44 207608 6889, E-Mail j.bainbridge@ ucl.ac.uk 
Fig. 1. Histology and corresponding schematic highlighting the vascular supply of the human retina. IS/OS = Inner and outer segments; ONL = outer nuclear layer; $\mathrm{OPL}=$ outer plexiform layer; $\mathrm{INL}=$ inner nuclear layer; IPL = inner plexiform layer; $\mathrm{GCL}=$ ganglion cell layer; $\mathrm{NFL}=$ nerve fibre layer.

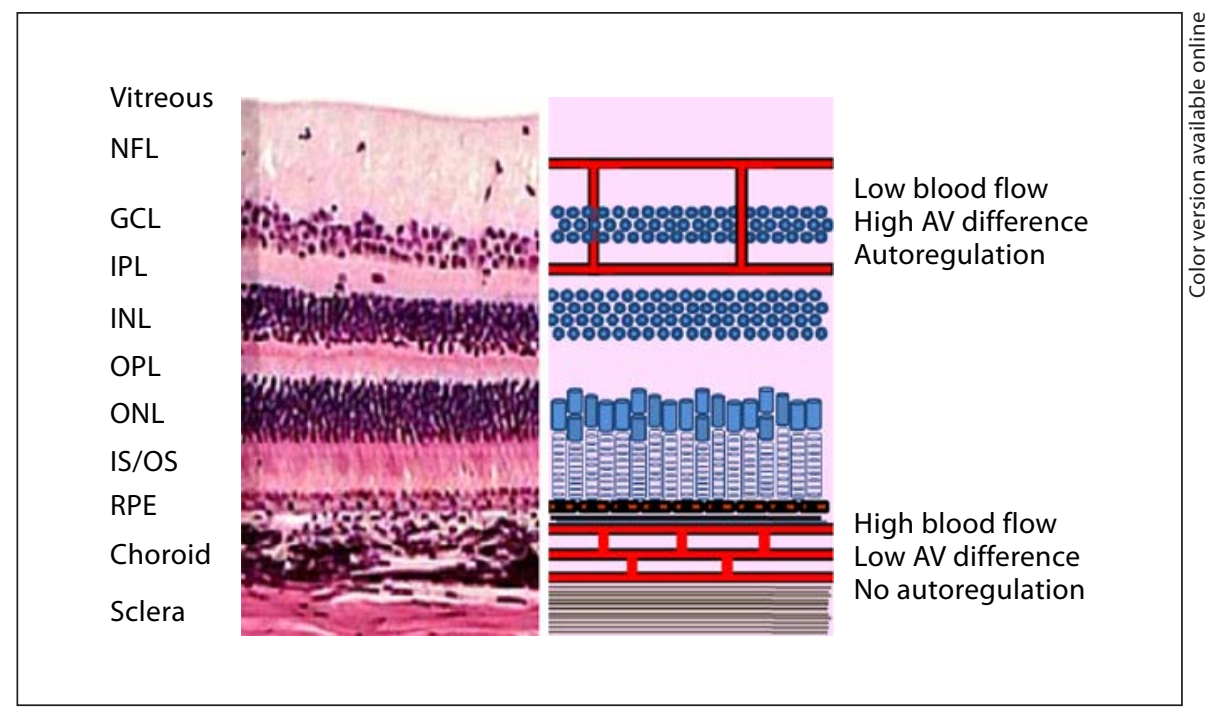

lease factors, including nitric oxide and endothelin, that modulate arterial tone, blood flow and oxygen delivery (for a detailed review, see Pournaras et al. [4]). The choroidal vasculature arises from long and short posterior ciliary arteries that pierce the sclera around the optic nerve to form 3 vascular layers that support the outer retina including photoreceptor cells [5]. The choroidal circulation has 20 -fold greater blood flow than the retinal circulation and a very low rate of oxygen extraction resulting in a low arteriovenous difference and a high reserve of oxygen transport capacity [6]. Choroidal vessels are surrounded by smooth muscle cells and controlled by a perivascular nervous plexus comprising both divisions of the autonomic nervous system $[7,8]$.

The profile of oxygen tension across the retina has been investigated using polarographic electrodes in several species including guinea pigs [9], cats [10], rats [11] and macaques [12]. Retinal oxygen tension is highest at the level of the choroid and falls steeply between the choriocapillaris and the outer plexiform layer under lightadapted conditions. Mathematical modelling suggests that oxygen consumption is maximal in inner segments of photoreceptor cells, amounting to $15-20 \mathrm{ml}$ per $100 \mathrm{~g}$ of tissue per minute in the dark, which is believed to reflect the metabolic demand of tightly packed mitochondria in this region [13]. In darkness, the partial pressure of oxygen in the outer retina is considerably lower, reaching $0 \mathrm{~mm} \mathrm{Hg}$ at the outer nuclear layer, while the partial pressure in the choroid is unchanged $[10,12]$. This finding reflects the increased oxygen consumption by photoreceptors in darkness, which is required for adenosine triphosphate (ATP) production for maintenance of the dark current, in which $\mathrm{Na}^{+}$ions are actively transported extracellularly by a $\mathrm{Na}^{+} / \mathrm{K}^{+}$ATPase pump [14]. The low oxygen tension in the outer retina in darkness results in a reversed oxygen gradient and oxygen diffusion from the inner retinal circulation to the outer retina (for a detailed review, see Wangsa-Wirawan and Linsenmeier [15]). In the cat, oxygen tension peaks in the inner and outer plexiform layers correspond to the superficial and deep retinal vascular plexi, respectively. The mean $\mathrm{pO}_{2}$ in the inner retina of the cat during dark adaptation is 18.5 $\mathrm{mm} \mathrm{Hg}$ [16], which is consistent with measurements of preretinal oxygen tension in cats of $18.9 \mathrm{~mm} \mathrm{Hg}$ [17]. Although no difference in oxygen consumption has been demonstrated between darkness and steady illumination $[18,19]$, the oxygen tension in the inner retina is slightly reduced in light adaptation compared with darkness [16].

Direct measurement of oxygen tension within the human retina has not been reported. However, preretinal oxygen tension is considered a valid indicator of inner retinal oxygen tension [20] and can be measured safely in humans. The mean oxygen tension at the inner limiting membrane in human subjects having surgery for idiopathic epiretinal membrane or full-thickness macular hole, conditions in which retinal oxygenation is believed to be normal, ranges between 9.8 and $15.0 \mathrm{~mm} \mathrm{Hg}$ depending on the site of measurement $[21,22]$.

Several lines of evidence demonstrated hypoxia in retinal vascular disease. Inner retinal oxygen tension is reduced by half in cats with diabetes [23], and hypoxia is evident on magnetic resonance imaging [24] and immu- 
nohistochemistry using the oxygen-dependent chemical probe pimonidazole in rodent models of diabetes [25]. Oxygen tension measured using an optical oxygen probe in humans with diabetes is reduced in the mid-vitreous, which is believed to reflect global oxygenation of the retina $[21,26]$. Indirect evidence of the role of hypoxia in early diabetic retinopathy includes hyperoxia-induced reversal of electroretinographic changes (early oscillatory potential reduction) [27], contrast sensitivity deficit [28] and macular oedema [29]. Experimental retinal vascular occlusion in animal models results in inner retinal inner hypoxia [30-33] and dysfunction [34] demonstrated by reduced b-wave amplitude on ERG [35]. In humans, central retinal vein occlusion is associated with reduced midvitreous oxygen levels [22]; while venular oxygen saturation is reduced, arteriolar saturation can be relatively spared [36].

Evidence also suggests that oxygen availability is involved in the pathogenesis of age-related macular degeneration (AMD). The aetiology of AMD involves a complex interaction of genetic susceptibility, oxidative stress, environmental influences and inflammatory processes (for a detailed review, see Ding et al. [37]). Outer retinal ischaemia and hypoxia have been implicated in the progression of the disease [38]. Individuals with AMD are more likely to have reduced choroidal perfusion [39-41] or watershed perfusion defects [42]. Thickening of Bruch's membrane, which increases the distance between the retina and the choroid, may further limit oxygen availability $[38,43]$.

\section{Oxygen Sensing in the Retina}

Retinal hypoxia can be caused by systemic cardiorespiratory failure or vascular insufficiency affecting the carotid or ophthalmic vessels or the retinal and/or choroidal circulations. Systemic hypoxia is sensed by chemoreceptors located near the respiratory centres in the brainstem medulla, and in the aortic and carotid body located on the aortic arch and at the bifurcation of the common carotid artery, respectively. The mechanisms of hypoxia sensing in chemoreceptors may involve hypoxiainduced depolarization of mitochondrial membranes or suppression of $\mathrm{K}^{+}$channels, resulting in membrane depolarization, calcium influx and secretion of neurotransmitters such as adenosine and dopamine [44]. The release of these factors activates efferent nerve fibres in the glossopharyngeal (carotid body) or the vagus nerve (aortic bodies) projecting to the nucleus tractus solitarii in the medulla. In close coordination with other brainstem mechanisms including baroreceptor stimulation, activation of sympathetic efferent pathways induces adaptive cardiorespiratory responses to hypoxia that include increased respiratory and cardiac rates, and modulation of regional blood flow by changes in vascular tone (for a detailed review, see Weir et al. [45]).

In addition to these systemic and regional responses, several mechanisms mediate adaptive responses to hypoxia within tissues at the cellular level to help ensure that vascular supply meets the local demand. Tissue sensing of oxygen availability in the retina is a fundamental biological process critical for appropriate adaptation to changing environments and physiological conditions and is also implicated in the pathogenesis of blinding retinal disorders including AMD, diabetic retinopathy and vaso-occlusive retinal disease. The retina responds rapidly to acute hypoxia by promoting blood flow and to sustained hypoxia by inducing expression of genes directing molecular and cellular responses that protect against hypoxic injury and redress an imbalance in supply and demand by controlling angiogenesis and metabolic requirement. Mechanisms of oxygen sensing in the retina include acute changes in transmembrane ion permeability, generation of vaso-active molecules, and stabilization of key transcription factors orchestrate multiple adaptive pathways to maintain oxygen homeostasis.

\section{Oxygen-Dependent Ion Channels}

Evidence for the likely role of hypoxia-dependent changes in ion permeability in the retina is based principally on the investigation of microvasculature of the central nervous system. The resting membrane potential and the contractile status in smooth muscle cells and pericytes is dependent upon the balance of $\mathrm{K}^{+}, \mathrm{Ca}^{2+}$ and $\mathrm{Cl}-$ channel activity. Oxygen-sensitive ion channels are believed to function as oxygen sensors and contribute to relaxation of vascular smooth muscle under hypoxic conditions. These channels may be stimulated directly by low oxygen or indirectly by changes secondary to hypoxia, including reduced ATP levels, increased adenosine diphosphate levels, and reduced intracellular $\mathrm{pH}$ [46]. ATPgated $\mathrm{K}^{+}$channels $\left(\mathrm{K}_{\mathrm{ATP}}\right)$ in smooth muscle cells may serve as a critical link between hypoxia and vasodilatation in cerebral arterioles during hypoxia. Under normoxic conditions, $\mathrm{K}_{\mathrm{ATP}}$ channels are inhibited by intracellular ATP. During hypoxia, a lack of ATP is accompanied by increased transmembrane $\mathrm{K}^{+}$flux, cell 
hyperpolarization, closure of voltage-dependent $\mathrm{Ca}^{2+}$ channels and a reduction in intracellular $\mathrm{Ca}^{2+}$ levels resulting in vasorelaxation and dilatation $[47,48]$. Furthermore, hypoxia reduces $\mathrm{Ca}^{2+}$ flux in smooth muscle cells by a direct effect on $\mathrm{Ca}^{2+}$ channels or indirectly by changes in ATP, pH, Ca ${ }^{2+}$ and $\mathrm{Mg}^{2+}$ [49-51]. The extent to which such changes in ion permeability upon hypoxia also occur in retinal and choroidal arteriolar smooth muscle cells and pericytes is not currently well defined.

\section{Oxygen-Dependent Vaso-Active Mediators}

Various vaso-active compounds including nitric oxide, hydrogen oxide, $\mathrm{K}^{+}$, adenosine, GABA, adrenomedullin (ADM), excitatory amino acids and others have been suggested as potential mediators of hypoxia-induced vasodilatation. Nitric oxide contributes to hypoxia-induced retinal vasodilatation and increased retinal blood flow in the cat [52]. Furthermore, hypoxia may induce glial-mediated secretion of a 'retinal relaxing factor', independent of nitric oxide, that induces retinal vasodilatation possibly by activating a membrane-bound $\mathrm{Ca}^{2+} /$ ATPase [53] The direct link between hypoxia and the secretion of these factors has not yet been identified but may depend on changes in ATP levels and ion currents in hypoxic glial cells (for a detailed review, see Pournaras et al. [4]).

\section{Oxygen-Dependent Transcription Factors}

Hypoxia-inducible transcription factors (HIFs) are heterodimeric transcription factors, each composed of 1 of the 3 oxygen-sensitive HIF- $\alpha$ subunits (HIF- $1 \alpha$, HIF$2 \alpha$ and HIF- $3 \alpha$ ) and the oxygen-insensitive and constitutively expressed HIF- $\beta$ subunit (ARNT). In normoxic conditions, HIFs are continuously and rapidly hydroxylated by 3 different catalyzing prolyl-4-hydroxylase isoforms (PHD 1-3) in a reaction that has an absolute requirement for molecular oxygen as a cosubstrate [54]. Hydroxylation of proline residues changes the conformation of HIF- $1 \alpha$ and increases the affinity of the von HippelLindau (VHL) protein and other factors including elongin $B$ and elongin $C$ [55], Cullin 2 [56] and RBX1 [57], which results in proteasomal proteolysis of HIF- $\alpha$ subunits by the ubiquitin-proteasome pathway $[58,59]$. In addition, HIF- $\alpha$ subunits are hydroxylated at a specific asparaginyl residue by another member of the 2-oxoglutarate-dependent oxygenase superfamily, which was originally identified as a protein that binds HIF and was named factor inhibiting HIF [60]. Asparaginyl hydroxylation abrogates the interaction between HIF-1 and the transcriptional co-activator $\mathrm{p} 300 / \mathrm{CBP}$ and provides a second oxygen-regulated mechanism by which HIF- $\alpha$ molecules that escape the prolyl hydroxylation/degradation pathway are prevented from activating gene transcription.

Under hypoxic conditions, in contrast, prolyl hydroxylation is suppressed and HIF- $\alpha$ subunits escape VHL protein-mediated degradation (fig. 2). Consequently, the $\alpha$ unit accumulates to high levels and is translocated to the nucleus where it dimerizes with the $\beta$ unit. The HIF$1 \alpha /$ HIF- $1 \beta$ dimer binds to $\mathrm{p} 300 / \mathrm{CBP}$ and activates the hypoxia response element in various hypoxia-responsive target genes. This triggers the transcription of many genes that facilitate adaption to low oxygen conditions including those encoding vascular endothelial growth factor (VEGF) [61], inducible nitric oxide synthase [62], erythropoietin (EPO) [63], endothelin-1 [64] and many others (for a detailed review, see Sharp and Bernaudin [65]). Although the increase of HIF-1 $\alpha$ in hypoxia is primarily controlled by the inhibition of the VHL degradation pathway, hypoxia also promotes translation of HIF$1 \alpha$ by stabilization of HIF mRNA in certain cell types [66]. Although originally identified as hypoxia-inducible factors, HIFs can also be activated in normoxia, for example in response to inflammatory processes [67].

\section{Localization and Target Genes of HIF- $\alpha$ Isoforms}

HIF- $1 \alpha$ and HIF- $2 \alpha$ are differentially expressed in different cells or tissues, resulting in activation of different target genes with non-overlapping functions. HIF- $1 \alpha$ is expressed ubiquitously and participates in most of the chronic cellular responses to low oxygen levels. HIF- $2 \alpha$ was originally thought to be restricted to endothelial cells and therefore initially named EPAS [68] but is more widely expressed than previously believed and is detected in non-endothelially derived tissues including lung, kidney, olfactory epithelium and adrenal gland [69]. Both Hifla [70] and Hif2a knockout mice [68] die in midgestation with multiple cardiovascular malformations and mesenchymal cell death, showing that each gene has critical non-redundant functions. Although HIF- $1 \alpha$ and HIF- $2 \alpha$ subunits are structurally similar in their dimerization domains and DNA binding sites, they differ in their transactivation domains, which results in specific target gene regulation [71]. Whereas HIF- $1 \alpha$ specifically regulates glycolytic genes $[72,73]$ as well as carbonic hydrase- 9 


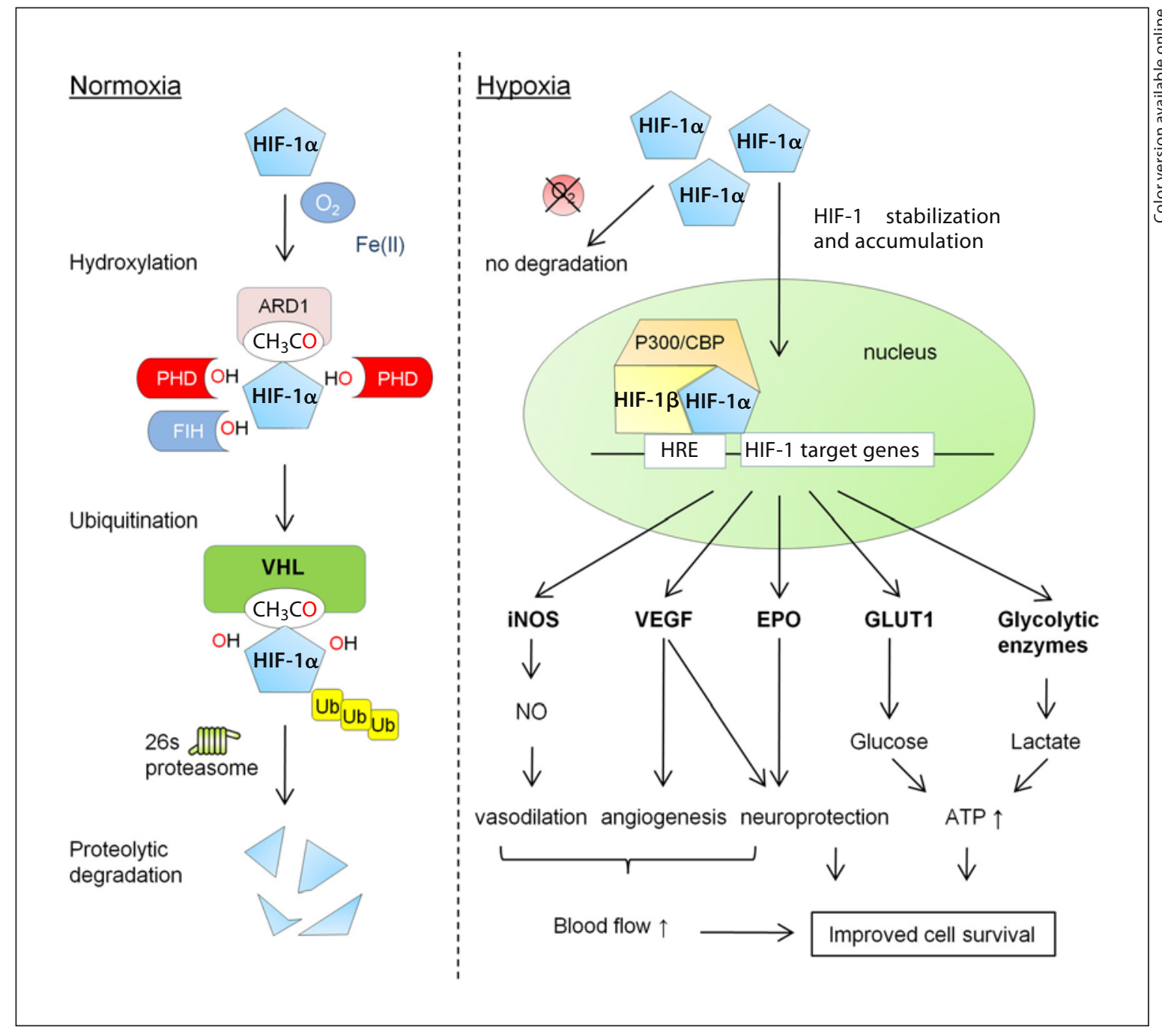

Fig. 2. Oxygen-dependent regulation and target genes of HIF-1 $\alpha$. In normoxia, HIF is hydroxylated by 'factor inhibiting HIF' (FIH1) and prolyl hydroxylase enzymes (PHD 1-3). In addition, ARD1 acetylates lysine (L) 532 in HIF-1 $\alpha$ to facilitate binding to the von Hippel-Lindau (VHL) protein. VHL binding to HIF serves as an E3 ubiquitin ligase to polyubiquitylate HIF-1 $\alpha$ and target HIF-1 $\alpha$

[74] and BNIP3 [75], HIF-2 $\alpha$ exclusively regulates other factors such as the transcription factor Oct- 4 , cyclin D1, and TGF- $\alpha$ [76]. Other hypoxia-inducible genes, such as VEGF, facilitated glucose transporter-1, adipose differentiation-related protein, and ADM are regulated by both HIF- $1 \alpha$ and HIF- $2 \alpha$ [72]. The role of HIF- $3 \alpha$ is poorly understood but may regulate the activity of other HIF- $\alpha$ isoforms as a dominant negative regulation of HIF-mediated control of gene expression [77].

Oxygen Sensing in Retinal Health and Disease for degradation in the proteasome. Under hypoxic conditions, hydroxylation of HIF does not occur, which prevents VHL binding. HIF- $1 \alpha$ accumulates in the cytosol and is translocated to the nucleus where it dimerizes with HIF-1 $\beta$ and activates hypoxia response element (HRE) in various hypoxia-responsive target genes.

\section{HIF Activation in the Retina}

Hypoxia-sensing mechanisms and HIFs are critical for normal retinal vascular development. During ocular development, Hifla co-localization with Vegf in ganglion cells and cells along the inner border of the neuroblastic layer of mice is consistent with a role in hypoxia, Vegf expression and physiological angiogenesis [78, 79]. Conditional inactivation of Hifla in the peripheral retina results in arrested development of the intermediate vascu-

Ophthalmologica 2012;227:115-131 
lar plexus [80], whereas overactivation of Hifs in the neuroretina leads to dysmorphic retinal vascular development and persistence of embryonic vascular structures into adulthood $[78,81]$. In healthy human and rat retina, HIF- $1 \alpha$ is detectable in the ganglion cell layer, inner nuclear layer, and outer nuclear layer suggesting that active HIF-1 signalling occurs constitutively and has a physiological role in the human retina [82].

There is accumulating evidence that HIFs also play a critical role in the pathogenesis of hypoxia-associated retinal vascular disease. During retinal hypoxia both HIF$1 \alpha$ and HIF- $2 \alpha$ are stabilized and the downstream molecules VEGF and EPO upregulated in the inner retina [83-85]. HIF- $1 \alpha$ is strongly activated in the ganglion cell and the inner nuclear layer, whereas HIF- $2 \alpha$ activation is restricted to a discrete subset of cells within the inner nuclear layer, most likely Muller glia, and to occasional astrocytes in the nerve fibre layer [84]. HIF- $\alpha$ activation in Muller cells appears to be important in the development of pathological retinal neovascularization. Conditional knockout of Hifla in Muller cells results in reduced Vegf expression and reduced preretinal neovascularization in oxygen-induced retinopathy [86]. Overexpression of Hif- $2 \alpha$, but not Hif- $1 \alpha$, in astrocytes induces Vegf and Epo expression in a mouse model of retinal hypoxia and the loss of Vegf or Hif- $2 \alpha$, but not Hif-1 $\alpha$, reduces pathological retinal neovascularization [87]. These findings underline the importance of HIFs in the development of retinal neovascularization and suggest distinct roles for HIF-1 and HIF-2 in retinal cell subtypes.

Substantial evidence indicates an important role for HIF in diabetic retinopathy. Hif- $1 \alpha$ is upregulated by hyperglycaemia in rodents $[86,88]$, and Hif- $2 \alpha$ is upregulated in the retina of mice with diabetes [89]. In humans, the concentrations of both HIF- $1 \alpha$ and VEGF are increased in the vitreous of patients with proliferative diabetic retinopathy and correlate with disease activity [90]. Other HIF-1 $\alpha$-dependent downstream molecules such as EPO [91], soluble VEGF receptor [92] and connective tissue growth factor (CTGF) [93] are increased in the vitreous of subjects with proliferative diabetic retinopathy. Furthermore, immunohistochemistry studies demonstrated a strong staining for HIF-1 $\alpha$ on surgically excised fibrovascular membranes from subjects with proliferative diabetic retinopathy $[94,95]$. These findings strongly suggest that HIFs are involved in the pathogenesis and progression of diabetic retinopathy by promoting adaptive responses to tissue hypoxia including the secretion of pro-angiogenic factors such as EPO, CTGF and VEGF. However, HIF-1 $\alpha$ can be stabilized in normoxia, for ex- ample by nitric oxide and reactive oxygen species in the inflammatory processes [96]. In advanced proliferative diabetic retinopathy, Lange et al. [21] identified no clear correlation between mid-vitreous hypoxia and VEGF levels, suggesting that other factors such as inflammation may contribute to retinal cytokine expression in this context. In central retinal vein occlusion, hypoxia and vitreous upregulation of VEGF [97] and EPO [98] are consistent with retinal activation of the HIF pathway.

Hypoxia-induced HIF activation may also promote choroidal neovascularization in AMD. Stefansson et al. [38] have suggested that hypoxia-induced expression of VEGF might paradoxically exacerbate hypoxia by inducing accumulation of subretinal fluid, with or without choroidal neovascularization and associated subretinal haemorrhage. HIF-1 and -2 expression is evident in RPE and choroidal neovascularization membranes $[99,100]$, with activation of HIF-2 $\alpha$ particularly prominent [100]. Activation of both Hif- $1 \alpha$ and Hif- $2 \alpha$ in the RPE by tissue-specific inactivation of Vhl leads to neovascularization in the outer retina with chorioretinal anastomosis in the mouse. Chorioretinal anastomosis develops despite additional inactivation of Hif- $1 \alpha$ in these animals, suggesting an important role for Hif- $2 \alpha$ in the RPE in choroidal neovascularization [101].

\section{Molecular and Cellular Adaptation to Retinal Hypoxia}

Retinal hypoxia can cause neuroretinal dysfunction and degeneration that lead directly to vision loss. The oxygen sensing mechanisms described above control adaptive responses that can help protect against ischaemic injury. These responses comprise rapid compensatory changes in blood flow and the activation of molecular and cellular mechanisms that protect against hypoxic injury and redress hypoxia by controlling angiogenesis and metabolic demand (table 1).

\section{Hypoxia-Induced Retinal Vasodilatation}

The inner retinal vasculature responds promptly to acute hypoxia by increasing vessel diameter and blood flow and thereby oxygen supply to the inner retina $[3,16$, $102,103]$. In humans, hypoxia leads to dilatation of retinal arterioles and venules by $8-9 \%$ within minutes [104]. Prolonged hypoxia, in humans at high altitude, can increase retinal vessel diameter by $24 \%$ [105]; retinal blood 
flow can increase by $89 \%$ within $2 \mathrm{~h}$ and by $174 \%$ after 7 weeks [102]. The mechanisms that underlie hypoxia-induced vasodilatation involve changes in ion permeability in vascular smooth muscle cells and local generation of vaso-active mediators (for a detailed review, see Pournaras et al. [4]). Choroidal blood flow is not significantly affected by moderate hypoxia suggesting that the choroidal circulation has excess capacity $[106,107]$. However, a substantial drop in venous oxygen saturation, such as can occur at prolonged high altitude, can induce increased choroidal blood flow that promotes oxygen delivery to the outer retina [107].

\section{Hypoxia-Induced Retinal Angiogenesis}

A causative association between retinal hypoxia and the development of retinal neovascularization was first suggested by Michaelson et al. [108] and further explored by Wise [109], who speculated that a hypoxia-induced growth factor 'factor $\mathrm{X}$ ' was responsible for inducing retinal neovascularization. Many candidate mediators have since been identified and VEGF has emerged as a particularly powerful pro-angiogenic growth factor [110]. VEGFs are a family of growth factors, expressed as a number of splice isoforms that vary in their length and affinity to heparin (for a detailed review, see Holmes and Zachary [111]). VEGFs bind to 2 high-affinity receptors, VEGFR1 [112] and VEGFR2 [113], promoting vascular permeability and proliferation of vascular endothelial cells in the eye [114], and facilitating the migration of vessels by inducing the production of matrix metalloproteinases [115]. VEGF signalling is essential for a normal development of the retinal and choroidal vasculature [116] and plays a central in the pathogenesis and progression of common disorders of the retina including diabetic retinopathy and AMD. Expression of VEGF is upregulated by activation of HIF-1 $\alpha$ in human retinal glial cells and RPE cells upon hypoxia $[117,118]$. Hypoxia-induced upregulation of VEGF expression is inhibited by siRNA against HIF-1 $\alpha$ [117] and in retinal ischaemia by hyperoxia, presumably by promoting VHL-induced prolyl hydroxylation of HIF- $\alpha$. In the retina, increased levels of HIF-1 $\alpha$ precede VEGF upregulation and correlate both spatially and temporally with the development of retinal neovascularization [84].

In addition to mediating upregulated expression of VEGF and VEGFR1, HIFs promote the expression of several other pro-angiogenic factors in hypoxia, including ADM [119] plasminogen activator inhibitor [120], CTGF
Table 1. Hypoxia-induced molecular mediators

\begin{tabular}{|c|c|c|}
\hline Proteins & Species & Reference \\
\hline \multicolumn{3}{|c|}{ Increased retinal activity upon hypoxia } \\
\hline HIF- $1 \alpha$ & rat & 182 \\
\hline HIF- $2 \alpha$ & mouse & 183 \\
\hline NMDAR1 & rat & 182 \\
\hline NMDAR2D & rat & 85 \\
\hline NMDAR2C & rat & 85 \\
\hline Flk1 & rat & 85 \\
\hline GluR2 & rat & 182 \\
\hline GluR3 & rat & 182 \\
\hline VEGF & rat & 184 \\
\hline IGF-I & rat & 185 \\
\hline IGF-II & rat & 185 \\
\hline Ang-2 & rat & 185 \\
\hline Nitric oxide & rat & 182 \\
\hline iNOS & rat & 182 \\
\hline eNOS & rat & 182 \\
\hline nNOS & rat & 182 \\
\hline iNOS & rat & 182 \\
\hline Flk1 & rat & 85 \\
\hline EPO & rat & 85 \\
\hline TNF- $\alpha$ & rat & 186 \\
\hline TNF receptor 1 & rat & 186 \\
\hline IL- $1 \beta$ & rat & 186 \\
\hline IL-1 receptor 1 & rat & 186 \\
\hline MCP-1 & rat & 186 \\
\hline CCR2 & rat & 186 \\
\hline \multicolumn{3}{|c|}{ Decreased retinal activity upon hypoxia } \\
\hline PEDF & rat & 185 \\
\hline
\end{tabular}

and tissue PAI [121]. ADM is a ubiquitously expressed peptide initially isolated from phaeochromocytoma [122] that protects endothelial cells against apoptosis (for a detailed review, see Ribatti et al. [123]). ADM is secreted from cultured human RPE in hypoxia [124] and associated with attenuation of ischaemia-induced injury [125]. CTGF controls growth, adhesion and survival of vascular endothelial cells (for a detailed review, see Perbal [126]). Plasminogen activator inhibitor is the principal inhibitor of fibrinolysis and has been associated with promoting angiogenesis (for a detail review, see Agirbasli [127]). Both CTGF and plasminogen activator-1 levels are upregulated by hypoxia in cultured human RPE cells via HIF-1 $\alpha$ [121]. The in vivo function of these molecules in the retina is not well-defined and further studies will be necessary to elucidate their role in hypoxia-driven physiological and pathological angiogenesis.

In the eye, the powerful angiogenic response to hypoxia is typically associated with oedema, haemorrhage 
Table 2. HIF target genes

\begin{tabular}{|c|c|c|}
\hline Role & HIF target genes & Ref. \\
\hline \multirow{7}{*}{$\begin{array}{l}\text { Vasomotor } \\
\text { control }\end{array}$} & $\mathrm{ADM}$ & 119 \\
\hline & nitric oxide synthase 2 (eNOS) & 187 \\
\hline & nitric oxide synthase 3 (iNOS) & 62 \\
\hline & $\alpha_{1 \mathrm{~B}}$-adrenergic receptor & 188 \\
\hline & endothelin 1 (ET1) & 189 \\
\hline & tyrosin hydroxylase & 190 \\
\hline & atrial natriuretic peptide & 191 \\
\hline \multirow{4}{*}{$\begin{array}{l}\text { Angio- } \\
\text { genesis }\end{array}$} & VEGF & 61 \\
\hline & FLT1 (VEGF receptor 1, VEGFR1) & 192 \\
\hline & plasminogen activator inhibitor-1 & 120 \\
\hline & apelin & 193 \\
\hline \multirow{2}{*}{$\begin{array}{l}\text { Hormonal } \\
\text { regulation/ } \\
\text { erythropoiesis }\end{array}$} & CTGF & 194 \\
\hline & EPO & 141 \\
\hline \multirow{3}{*}{$\begin{array}{l}\text { Iron } \\
\text { metabolism }\end{array}$} & transferrin & 195 \\
\hline & transferrin receptor & 196 \\
\hline & ceruloplasmin & 197 \\
\hline \multirow{7}{*}{$\begin{array}{l}\text { Cell cycle } \\
\text { control }\end{array}$} & DMT1 & 198 \\
\hline & p21 (WAF1/CIP1) & 199 \\
\hline & insulin-like growth factor 2 (IGF2) & 200 \\
\hline & IGFBP1, IGFBP2, IGFBP3 & 201 \\
\hline & endoglin & 202 \\
\hline & Wilms' tumour suppressor & 203 \\
\hline & $\alpha$-fetoprotein (negative regulation) & 204 \\
\hline \multirow[t]{3}{*}{ Cell death } & calcitonin-receptor-like receptor & 205 \\
\hline & NIP3, NIX & 206 \\
\hline & P53 & 207 \\
\hline $\begin{array}{l}\text { Cell } \\
\text { migration }\end{array}$ & CXCR4 & 208 \\
\hline \multirow{14}{*}{$\begin{array}{l}\text { Energy } \\
\text { metabolism }\end{array}$} & glucose transporters 1 and 3 (GLUT1, GLUT3) & 133 \\
\hline & prolyl-4-hydroxylase $\alpha_{1}$ & 209 \\
\hline & phosphofructokinase & 210 \\
\hline & lactate dehydrogenase $\mathrm{A}$ & 210 \\
\hline & aldolases $\mathrm{A}$ and $\mathrm{C}$ & 210 \\
\hline & pyruvate kinase $\mathrm{M}$ & 210 \\
\hline & enolase 1 & 210 \\
\hline & hexokinases 1 and 2 & 70 \\
\hline & Max interactor & 211 \\
\hline & pyruvate dehydrogenase kinase & 212 \\
\hline & monocarboxylate transporter 4 & 213 \\
\hline & cytochrome oxidase isoform 2 & 214 \\
\hline & glyceraldehyde phosphate dehydrogenase & 215 \\
\hline & 6-phospho-2-kinase/fructose 2,6 bisphosphatase & 216 \\
\hline \multirow{8}{*}{$\begin{array}{l}\text { Miscella- } \\
\text { neous }\end{array}$} & plasminogen activator inhibitor (PAI1) 38 & 120 \\
\hline & transforming growth factor $\beta 3$ (TGF $\beta 3$ ) & 217 \\
\hline & haem oxygenase 1 & 218 \\
\hline & adenylate kinase 3 & 219 \\
\hline & phosphoglycerate kinase 1 & 210 \\
\hline & carbonic anhydrase 9 & 220 \\
\hline & leptin & 221 \\
\hline & Rab20 & 222 \\
\hline
\end{tabular}

and fibrosis that can exacerbate hypoxic neuroretinal injury, causing severe vision loss [128]. In ischaemic retinal diseases such as diabetic retinopathy, retinal neovascularization typically fails to revascularize the ischaemic neuroretina appropriately, and instead is paradoxically misdirected toward the vitreous and into the iridocorneal angle leading to vitreous haemorrhage, tractional retinal detachment, aqueous outflow obstruction and glaucoma. The reason for this misdirection is not well understood but may depend on nitric oxide signalling, which is increased in ischaemic retinal vascular disease $[129,130]$. Sennlaub et al. [131] demonstrated that inducible nitric oxide synthase is expressed in the ischaemic mouse retina and inhibits its revascularization at least in part by downregulation of VEGF receptor 2. More recent evidence suggests that the neuronal guidance cue semaphorin $3 \mathrm{~A}$ (Sema3A), which is secreted by hypoxic neurons, repels neovessels toward the vitreous. Silencing of Sema3A expression enhances normal vascular regeneration within the ischaemic retina, restores metabolic supply, diminishes aberrant neovascularization and preserves neuroretinal function [132]. In AMD, VEGF-induced choroidal neovascularization, which may be the result of both hypoxic and inflammatory activation of HIFs, typically exacerbates retinal injury with exudation, haemorrhage and fibrosis.

\section{Hypoxia-Induced Retinal Metabolic Adaption}

A critical adaptation to hypoxia is the ability of cells to utilize glucose by means other than mitochondrial oxidative phosphorylation, for which oxygen is an absolute requirement. Hypoxic activation of HIF-1 $\alpha$ shifts energy production from mitochondrial to glycolytic sources by inducing a wide range of genes involved in glucose metabolism (table 2) including those such as glucose transporter-1 that promote glucose transport into the hypoxic cell $[133,134]$. In addition, HIF- $1 \alpha$ promotes expression of enzymes responsible for the glycolysis of intracellular glucose such as aldolase A [70], hexokinases 1 and 2 and phosphofructokinase $1[135,136]$. Under normoxic conditions, pyruvate can be metabolized by oxygen-dependent mitochondrial oxidative phosphorylation to generate ATP efficiently. In hypoxia, however, pyruvate is converted by lactate dehydrogenase to lactate with less efficient generation of ATP. Hypoxic activation of HIF- $1 \alpha$ also downregulates mitochondrial function and oxidative phosphorylation by promoting the expression of genes such as pyruvate dehydrogenase kinase 1 [137] and 
MAX interactor 1 [138], ultimately leading to reduced oxygen demand and consumption. The effect of these mechanisms is to compensate for hypoxia by reducing the oxygen demand while maintaining a supply of energy. In the retina, hypoxia induces an increase in extracellular concentration of lactate and increased utilization of glucose [139]. Lactate and glucose accumulates in the vitreous in proliferative diabetic retinopathy [140] and induction of hypoxia-responsive genes by cobalt chloride increases the expression of Glut 1 and Glut 3 in the neuroretina. Taken together, these findings are consistent with a shift in energy production from mitochondrial phosphorylation to anaerobic glycolysis induced by hypoxia in the retina.

\section{Hypoxia-Induced Retinal Neuroprotection}

Accumulating evidence indicates that HIF-dependent expression of EPO can protect the retina against injury. EPO is a glycoprotein produced in hepatocytes during development and by renal interstitial fibroblasts in the adult, in an oxygen-dependent manner controlled by HIF-1 $\alpha$ [141], and acts as a hormone to regulate production of red blood cells in the bone marrow by preventing apoptosis of erythroid progenitor cells. In addition to its known function of stimulating haematopoiesis, EPO is expressed in many other adult tissues, including the spleen, the brain and the retina [142] indicating a paracrine function. EPO and its receptor are expressed in the human neuroretina and to a significantly higher extent in the retinal pigment epithelium [143]. Hypoxia-induced stabilization of both HIF- $1 \alpha$ and HIF- $2 \alpha$ is associated with increased EPO expression in the eye [84, 144]. Activation of EPO receptors, which are expressed in photoreceptors [144] and in the ganglion cell layer in rodents [145], lead to autophosphorylation and activation of multiple signal transduction pathways including the Jak/ STAT5 and AKT pathways that have multiple effects on gene transcription, caspase activation and inflammation (for a detailed review, see Li et al. [146]). EPO protects neuronal cells in vitro and in vivo by reducing nitric oxide-induced free radical damage [147]. Endogenous EPO is implicated in hypoxic preconditioning that protects photoreceptors against light-induced apoptosis [144, 148] and can protect the retina against ischaemia-induced dysfunction [84]. Systemic EPO supplementation protects ganglion cells against ischaemia [148] and can protect the retinal vasculature against oxygen-induced vasoobliteration [149]. Reduction in local EPO by inhibition of HIF- $1 \alpha$ using YC-1 is associated with inhibition of pathological retinal neovascularization [150]. Taken together, these findings indicate that EPO can promote protective adaptive responses to hypoxia in the retina and suggest that it has potential value for therapeutic intervention in retinal ischaemia. However, since EPO supplementation can exacerbate pathological retinal neovascularization [149], the possibility of adverse effects will require careful evaluation.

\section{Therapeutic Intervention for Retinal Hypoxia}

Hypoxia resulting from disorders of retinal perfusion should be addressed clinically by appropriately managing specific underlying causes. For example, endarterectomy is conventional management for carotid stenosis, and optimal management of blood glucose blood pressure (and perfusion pressure) can slow progression of retinal vascular disease [151, 152]. Experimental interventions for retinal vascular occlusions include radial optic neurotomy for central retinal vein occlusion, adventitial sheathotomy for branch retinal vein occlusion, and embolectomy for branch retinal artery occlusion. In addition to redressing perfusion deficits, the availability of oxygen to the retina may be enhanced by increasing the supply or by reducing the demand for oxygen itself. Increased oxygen delivery may be achieved by inhalation of hyperbaric or supplemental oxygen. Hyperbaric oxygen treatment is reported to ameliorate the blood-retinal barrier breakdown in diabetic retinopathy in rats [153]. Supplemental inhaled oxygen for 3 months was associated with improved diabetic macular oedema [29]. While these interventions are unlikely to provide practical treatment options, the findings provide further evidence of the importance of hypoxia in diabetic retinopathy.

\section{Improving Inner Retinal Oxygenation by Panretinal Photocoagulation}

Panretinal photocoagulation (PRP) promotes regression of pathological retinal neovascularization and is a conventional treatment for proliferative retinopathies associated with chronic ischaemia. PRP causes thermal destruction of retinal pigment epithelial cells and adjacent photoreceptors, which are replaced by glial cells with relatively low oxygen consumption $[154,155]$. Reduced local consumption of oxygen at sites of photocoagulation is believed to promote oxygen diffusion from the choroidal 
circulation to the inner retina and to relieve inner retinal hypoxia locally [156]. Evidence supporting this hypothesis has been described in the cat [157], the pig [158], the rabbit [159], and in the human [160]. Application of PRP is followed by vascular constriction consistent with autoregulatory adaption to locally increased oxygenation [161] and with reduction in VEGF and VEGF receptor levels in the vitreous $[110,162]$. Although PRP offers a powerful technique to protect central vision against the consequences of retinal neovascularization, conventional photocoagulation strategies cause predictable adverse impact on peripheral vision, contrast sensitivity and night vision, and safer alternative approaches are highly desirable.

\section{Improving Inner Retinal Oxygenation by Vitrectomy}

Vitrectomy can reduce retinal neovascularization and macular oedema $[163,164]$ while increasing the rate of cataract formation and iris neovascularization $[165,166]$. These clinical observations may be explained by changes in ocular oxygenation associated with the promotion of fluid currents in the vitreous cavity [156]. The vitreous gel has a relatively low oxygen tension, possibly maintained by a high ascorbate content that acts as an oxygen sink to protect the lens from oxidative damage [167]. The removal of vitreous gel and its replacement with aqueous facilitates diffusion of both oxygen and growth factors. Vitrectomy results in increased oxygen tension in the mid-vitreous and is associated with accelerated development of nuclear sclerotic lens opacity $[26,26]$. Vitrectomy may promote diffusion of oxygen to the retina from the anterior segment [32], and possibly from better-perfused areas of the retina to areas of retinal hypoxia [21]. Conversely, increased clearance of hypoxia-induced vaso-active growth factors such as VEGF from the eye following vitrectomy may account for iris neovascularization and neovascular glaucoma (for a detailed review, see Stefansson [168]).

\section{Improving Inner Retinal Oxygenation by Maintaining Light Adaptation}

Arden et al. [169] have suggested that inner retinal hypoxia in diabetes may be aggravated by dark adaptation because the metabolically demanding dark current of photoreceptor cells in the outer retina reduces availability of oxygen to the inner retina. They further postulated that progression of diabetic retinopathy may be controlled by minimizing dark adaptation to promote retinal oxygen availability. Preliminary reports suggest that application of trans-lid retinal illumination during sleep to one eye of subjects with non-proliferative diabetic is associated with improved outcome [170].

\section{Therapeutic Targeting of HIF Signalling}

As an alternative to improving retinal oxygen supply, the retina may be protected against the effects of local hypoxia by manipulating adaptive responses so as to inhibit harmful consequences and, potentially, to promote beneficial adaptive responses. Intra-ocular delivery of anti-VEGF antibodies can effectively control pathological neovascularization and oedema. Clinical trials of VEGF inhibitors have demonstrated a significant benefit in AMD [171] and considerable potential in diabetic retinopathy [172]. While these results demonstrate the enormous potential of local anti-angiogenic therapy for retinal vascular disease, there are considerable limitations. The short half-lives of Vegf antibodies in the eye necessitate multiple repeated intra-ocular injections that are not cost effective and cumulatively increase the risk of sight-threatening local adverse effects. Furthermore, anti-VEGF therapy has been associated with systemic adverse effects including non-ocular haemorrhage and stroke [173]. While non-specific VEGF inhibitors target aberrant angiogenesis, they fail to address the underlying hypoxia and to consider appropriate endogenous compensatory responses including neuroprotective mechanisms and appropriate vascular remodelling. While antiVEGF therapies are valuable for targeting neovascular disease, future therapeutic strategies should consider how to protect and promote appropriate retinal responses to hypoxia. Improved understanding of oxygen sensing and the HIF pathway is likely to help identify new therapeutic opportunities to promote neuroprotection and appropriate vascular remodelling, while protecting against hypoxic/oxidative stress and pathological angiogenesis.

Based on its central role as a master regulator of responses to hypoxia/ischaemia, HIF is a potentially relevant target for treating vascular disease in the eye. HIF signalling can be manipulated by interfering with its expression using siRNA, by direct protein inhibition using small inhibitors, or by inhibition or activation of its degradation by inferring with VHL or PHD activity. Systemic stabilization of Hif by inhibition of prolyl hydroxylases 
can protect against oxygen-induced retinopathy [174]. This finding is consistent with an observed protective effect of Epo supplementation on vascular and neuronal survival in the early phase of this model [149]. Furthermore, HIF- $1 \alpha$ stabilization by pyruvate is neuroprotective in a model of light-induced retinal degeneration [175]. Systemic stabilization of HIF in the proliferative stage of the oxygen-induced retinopathy model, however, exacerbates pathological neovascularization [174]. Systemic administration of digoxin was reported to reduce HIF- $1 \alpha$ levels in the proliferative stage and to suppress retinal and choroidal neovascularization [176]. Intra-ocular administration might minimize the potential for systemic side effects of HIF inhibitors [177, 178]. Intravitreal injection of anti-HIF-1 $\alpha$ short hairpin RNAs in nanoparticles inhibits experimental choroidal neovascularization [179]. Overexpression of VHL reduces HIF-1 $\alpha$ levels and inhibits intra-ocular angiogenesis in laser-induced retinal vein occlusion in monkeys [180]. Furthermore, a small molecule inhibitor of HIF- $1 \alpha$, which is currently undergoing clinical trials in cancer treatment [181], improves physiological revascularization, and reduces pathological neovascularization in the retina of mice [150].

Activation of HIF signalling, for example by prolyl hydroxlyase inhibition, offers a potential therapeutic option to improve ischaemic tolerance in retinal vascular disease by upregulating beneficial HIF-dependent processes such as metabolic adaptation, neuroprotection and appropriate revascularization [174]. Conversely, inactivation of HIF signalling, for example by controlled activation of PHDs, may control pathological neovascularization in retinal ischaemia. Given the complexity of the HIF signalling system, in which multiple PHD and HIF isoforms regulate the transcription of numerous genes that intersect with multiple other signalling pathways, successful intervention is likely to depend on careful molecular targeting and timing of intervention. Whether or not targeting of PHDs can be sufficiently selective to avoid non-therapeutic effects, retaining the pleiotropy that distinguishes PHD inhibition or activation from therapeutic targeting of specific downstream HIF-regulated gene products will require careful investigation. Target specificity may be improved by defining the cellular distribution of the PHD isoforms and their interaction with HIF isoforms in the retina, with a view to cellspecific targeting.

\section{Conclusion}

Sophisticated molecular processes have evolved to help ensure that tissue oxygen availability meets local demand. In this review, we summarize the current understanding of oxygen sensing mechanisms in retinal health and disease. In the retina, powerful molecular mechanisms mediate responses to alterations in oxygen availability with adaptive changes in blood flow, metabolism and angiogenesis. In the eye, the angiogenic response to hypoxia is aberrant and can exacerbate hypoxic neuroretinal injury, leading to severe vision loss. A key response is mediated and coordinated by the transcription factor HIF-1 that is central to embryonic development and disorders of retinal ischaemia. Manipulation of this response by activation or inhibition of HIFs or PHDs offer potential therapeutic approaches to promote appropriate adaptive mechanisms and protect against inappropriate effects that exacerbate ischaemic injury. Although the molecular mechanisms of HIF- $\alpha$ isoforms and PHDs have been the subject of extensive investigation, their roles in the retina appear to be contextual with significant cellular specificity. Detailed investigation of these mechanisms in the retina will help determine whether targeted intervention upstream in this pathway can take advantage of pleotropic downstream effects without significant risk of adverse consequences.

\section{References}

1 Provis JM: Development of the primate retinal vasculature. Prog Retin Eye Res 2001;20: 799-821.

-2 Hickam JB, Sieker HO, Frayser R: Studies of retinal circulation and $\mathrm{A}-\mathrm{V}$ oxygen difference in man. Trans Am Clin Climatol Assoc 1959;71:34-44.

-3 Hickam JB, Frayser R: Aphotographic method for measuring the mean retinal circulation time using fluorescein. Invest Ophthalmol 1965;4:876-884.

\footnotetext{
-4 Pournaras CJ, Rungger-Brandle E, Riva CE, Hardarson SH, Stefansson E: Regulation of retinal blood flow in health and disease. Prog Retin Eye Res 2008;27:284-330.

5 Hayreh SS: Physiological anatomy of the choroidal vascular bed. Int Ophthalmol 1983;6:85-93.
} 
$>8$ Lutjen-Drecoll E: Choroidal innervation in primate eyes. Exp Eye Res 2006;82:357-361.

$\checkmark 9$ Pournaras CJ, Riva CE, Tsacopoulos M, Strommer K: Diffusion of $\mathrm{O}_{2}$ in the retina of anesthetized miniature pigs in normoxia and hyperoxia. Exp Eye Res 1989;49:347360.

10 Linsenmeier RA: Effects of light and darkness on oxygen distribution and consumption in the cat retina. J Gen Physiol 1986;88: 521-542.

- 11 Yu DY, Cringle SJ, Alder VA, Su EN: Intraretinal oxygen distribution in rats as a function of systemic blood pressure. Am J Physiol 1994;267:H2498-H2507.

-12 Ahmed J, Braun RD, Dunn R Jr, Linsenmeier RA: Oxygen distribution in the macaque retina. Invest Ophthalmol Vis Sci 1993;34:516521.

13 Haugh LM, Linsenmeier RA, Goldstick TK: Mathematical models of the spatial distribution of retinal oxygen tension and consumption, including changes upon illumination. Ann Biomed Eng 1990;18:19-36.

- 14 Kimble EA, Svoboda RA, Ostroy SE: Oxygen consumption and ATP changes of the vertebrate photoreceptor. Exp Eye Res 1980;31: 271-288.

15 Wangsa-Wirawan ND, Linsenmeier RA: Retinal oxygen: fundamental and clinical aspects. Arch Ophthalmol 2003;121:547-557.

-16 Linsenmeier RA, Braun RD: Oxygen distribution and consumption in the cat retina during normoxia and hypoxemia. J Gen Physiol 1992;99:177-197.

17 Alm A: Effects of norepinephrine, angiotensin, dihydroergotamine, papaverine, isoproterenol, histamine, nicotinic acid, and xanthinol nicotinate on retinal oxygen tension in cats. Acta Ophthalmol (Copenh) 1972;50: 707-719.

-18 Medrano CJ, Fox DA: Oxygen consumption in the rat outer and inner retina: light- and pharmacologically-induced inhibition. Exp Eye Res 1995;61:273-284.

19 Alder VA, Cringle SJ: Vitreal and retinal oxygenation. Graefes Arch Clin Exp Ophthalmol 1990;228:151-157.

-20 Linsenmeier RA, Goldstick TK, Blum RS, Enroth-Cugell C: Estimation of retinal oxygen transients from measurements made in the vitreous humor. Exp Eye Res 1981;32: 369-379.

21 Lange CA, Stavrakas P, Luhmann UF, de Silva DJ, Ali RR, Gregor ZJ, Bainbridge JW: Intraocular oxygen distribution in advanced proliferative diabetic retinopathy. Am J Ophthalmol 2011, E-pub ahead of print.

-22 Williamson TH, Grewal J, Gupta B, Mokete $\mathrm{B}$, Lim M, Fry CH: Measurement of $\mathrm{PO}_{2}$ during vitrectomy for central retinal vein occlusion, a pilot study. Graefes Arch Clin Exp Ophthalmol 2009;247:1019-1023.
23 Linsenmeier RA, Braun RD, McRipley MA, Padnick LB, Ahmed J, Hatchell DL, McLeod DS, Lutty GA: Retinal hypoxia in long-term diabetic cats. Invest Ophthalmol Vis Sci 1998;39:1647-1657.

24 Trick GL, Berkowitz BA: Retinal oxygenation response and retinopathy. Prog Retin Eye Res 2005;24:259-274.

25 de Gooyer TE, Stevenson KA, Humphries P, Simpson DA, Gardiner TA, Stitt AW: Retinopathy is reduced during experimental diabetes in a mouse model of outer retinal degeneration. Invest Ophthalmol Vis Sci 2006; 47:5561-5568.

26 Holekamp NM, Shui YB, Beebe D: Lower intraocular oxygen tension in diabetic patients: possible contribution to decreased incidence of nuclear sclerotic cataract. Am J Ophthalmol 2006;141:1027-1032.

27 Drasdo N, Chiti Z, Owens DR, North RV: Effect of darkness on inner retinal hypoxia in diabetes. Lancet 2002;359:2251-2253.

28 Harris A, Arend O, Danis RP, Evans D, Wolf S, Martin BJ: Hyperoxia improves contrast sensitivity in early diabetic retinopathy. Br J Ophthalmol 1996;80:209-213.

29 Nguyen QD, Shah SM, Van AE, Sung JU, Vitale S, Campochiaro PA: Supplemental oxygen improves diabetic macular edema: a pilot study. Invest Ophthalmol Vis Sci 2004;45 617-624.

30 Pournaras CJ, Tsacopoulos M, Strommer K, Gilodi N, Leuenberger PM: Experimental retinal branch vein occlusion in miniature pigs induces local tissue hypoxia and vasoproliferative microangiopathy. Ophthalmology 1990;97:1321-1328.

-31 Bardy M, Tsacopoulos M: Metabolic changes in the retina after experimental microembolism in the miniature pig (author's transl). Klin Monbl Augenheilkd 1978;172:451-460.

-32 Stefansson E, Landers MB III, Wolbarsht ML: Increased retinal oxygen supply following pan-retinal photocoagulation and vitrectomy and lensectomy. Trans Am Ophthalmol Soc 1981;79:307-334.

33 Pournaras CJ, Ilic J, Gilodi N, Tsacopoulos M, Leuenberger MP: Experimental venous thrombosis: preretinal $\mathrm{PO}_{2}$ before and after photocoagulation. Klin Monbl Augenheilkd 1985;186:500-501

34 Donati G, Kapetanios A, Dubois-Dauphin M, Pournaras CJ: Caspase-related apoptosis in chronic ischaemic microangiopathy following experimental vein occlusion in minipigs. Acta Ophthalmol 2008;86:302-306.

35 Zhang Y, Fortune B, Atchaneeyasakul LO, McFarland T, Mose K, Wallace P, Main J, Wilson D, Appukuttan B, Stout JT: Natural history and histology in a rat model of laserinduced photothrombotic retinal vein occlusion. Curr Eye Res 2008;33:365-376.

>36 Hardarson SH, Stefansson E: Oxygen saturation in central retinal vein occlusion. Am J Ophthalmol 2010;150:871-875.
37 Ding X, Patel M, Chan CC: Molecular pathology of age-related macular degeneration. Prog Retin Eye Res 2009;28:1-18.

38 Stefansson E, Geirsdottir A, Sigurdsson H: Metabolic physiology in age related macular degeneration. Prog Retin Eye Res 2011;30: 72-80.

\$3 Metelitsina TI, Grunwald JE, DuPont JC, Ying GS, Brucker AJ, Dunaief JL: Foveolar choroidal circulation and choroidal neovascularization in age-related macular degeneration. Invest Ophthalmol Vis Sci 2008;49: 358-363.

40 Grunwald JE, Hariprasad SM, DuPont J, Maguire MG, Fine SL, Brucker AJ, Maguire AM, Ho AC: Foveolar choroidal blood flow in age-related macular degeneration. Invest Ophthalmol Vis Sci 1998;39:385-390.

$\checkmark 4$ Grunwald JE, Metelitsina TI, DuPont JC, Ying GS, Maguire MG: Reduced foveolar choroidal blood flow in eyes with increasing AMD severity. Invest Ophthalmol Vis Sci 2005;46:1033-1038.

42 Chen SJ, Cheng CY, Lee AF, Lee FL, Chou JC, Hsu WM, Liu JH: Pulsatile ocular blood flow in asymmetric exudative age related macular degeneration. Br J Ophthalmol 2001;85: 1411-1415.

43 Bird AC: Choroidal neovascularisation in age-related macular disease. Br J Ophthalmol 1993;77:614-615.

44 Lahiri S, Roy A, Baby SM, Hoshi T, Semenza GL, Prabhakar NR: Oxygen sensing in the body. Prog Biophys Mol Biol 2006;91:249286.

45 Weir EK, Lopez-Barneo J, Buckler KJ, Archer SL: Acute oxygen-sensing mechanisms. N Engl J Med 2005;353:2042-2055.

46 Lopez-Barneo J, Ortega-Saenz P, Molina A, Franco-Obregon A, Urena J, Castellano A: Oxygen sensing by ion channels. Kidney Int 1997;51:454-461.

47 Standen NB, Quayle JM, Davies NW, Brayden JE, Huang Y, Nelson MT: Hyperpolarizing vasodilators activate ATP-sensitive $\mathrm{K}^{+}$channels in arterial smooth muscle. Science 1989;245:177-180.

48 Daut J, Maier-Rudolph W, von BN, Mehrke G, Gunther K, Goedel-Meinen L: Hypoxic dilation of coronary arteries is mediated by ATP-sensitive potassium channels. Science 1990;247:1341-1344.

49 Ohya Y, Sperelakis N: Fast $\mathrm{Na}^{+}$and slow $\mathrm{Ca}^{2+}$ channels in single uterine muscle cells from pregnant rats. Am J Physiol 1989;257:C408C412.

50 Okashiro T, Tokuno H, Fukumitsu T, Hayashi H, Tomita T: Effects of intracellular ATP on calcium current in freshly dispersed single cells of guinea-pig portal vein. Exp Physiol 1992;77:719-731.

-51 Rekalov V, Juranek I, Malekova L, Bauer $\mathrm{V}$ : Hypoxia-induced inhibition of calcium channels in guinea-pig taenia caeci smooth muscle cells. J Physiol 1997;505:107-119. 
-52 Nagaoka T, Sakamoto T, Mori F, Sato E, Yoshida A: The effect of nitric oxide on retinal blood flow during hypoxia in cats. Invest Ophthalmol Vis Sci 2002;43:3037-3044.

53 Maenhaut N, Boussery K, Delaey C, Van de Voorde J: Adenosine enhances the relaxing influence of retinal tissue. Exp Eye Res 2009; 88:71-78.

54 Bruick RK, McKnight SL: A conserved family of prolyl-4-hydroxylases that modify HIF. Science 2001;294:1337-1340.

55 Kibel A, Iliopoulos O, DeCaprio JA, Kaelin WG Jr: Binding of the von Hippel-Lindau tumor suppressor protein to Elongin B and C. Science 1995;269:1444-1446.

-56 Pause A, Lee S, Worrell RA, Chen DY, Burgess WH, Linehan WM, Klausner RD: The von Hippel-Lindau tumor-suppressor gene product forms a stable complex with human CUL-2, a member of the Cdc53 family of proteins. Proc Natl Acad Sci USA 1997;94:2156 2161.

-57 Iwai K, Yamanaka K, Kamura T, Minato N, Conaway RC, Conaway JW, Klausner RD, Pause A: Identification of the von HippelLindau tumor-suppressor protein as part of an active E3 ubiquitin ligase complex. Proc Natl Acad Sci USA 1999;96:12436-12441.

58 Maxwell PH, Wiesener MS, Chang GW, Clifford SC, Vaux EC, Cockman ME, Wykoff CC, Pugh CW, Maher ER, Ratcliffe PJ: The tumour suppressor protein VHL targets hypoxia-inducible factors for oxygen-dependent proteolysis. Nature 1999;399:271-275.

-59 Ivan M, Kondo K, Yang H, Kim W, Valiando J, Ohh M, Salic A, Asara JM, Lane WS, Kaelin WG Jr: HIFalpha targeted for VHL-mediated destruction by proline hydroxylation: implications for $\mathrm{O}_{2}$ sensing. Science 2001;292: 464-468.

60 Mahon PC, Hirota K, Semenza GL: FIH-1: a novel protein that interacts with HIF-1alpha and VHL to mediate repression of HIF-1 transcriptional activity. Genes Dev 2001;15: 2675-2686.

61 Forsythe JA, Jiang BH, Iyer NV, Agani F, Leung SW, Koos RD, Semenza GL: Activation of vascular endothelial growth factor gene transcription by hypoxia-inducible factor 1. Mol Cell Biol 1996;16:4604-4613.

62 Melillo G, Musso T, Sica A, Taylor LS, Cox GW, Varesio L: A hypoxia-responsive element mediates a novel pathway of activation of the inducible nitric oxide synthase promoter. J Exp Med 1995;182:1683-1693.

63 Wang GL, Semenza GL: Molecular basis of hypoxia-induced erythropoietin expression. Curr Opin Hematol 1996;3:156-162.

64 Hu J, Discher DJ, Bishopric NH, Webster KA: Hypoxia regulates expression of the endothelin-1 gene through a proximal hypoxia-inducible factor-1 binding site on the antisense strand. Biochem Biophys Res Com mun 1998;245:894-899.
65 Sharp FR, Bernaudin M: HIF1 and oxygen sensing in the brain. Nat Rev Neurosci 2004 5:437-448

66 Bergeron M, Yu AY, Solway KE, Semenza GL, Sharp FR: Induction of hypoxia-inducible factor-1 (HIF-1) and its target genes following focal ischaemia in rat brain. Eur J Neurosci 1999;11:4159-4170.

67 Olson N, van der Vliet A: Interactions between nitric oxide and hypoxia-inducible factor signaling pathways in inflammatory disease. Nitric Oxide 2011;25:125-137.

68 Tian H, McKnight SL, Russell DW: Endothelial PAS domain protein 1 (EPAS1), a transcription factor selectively expressed in en dothelial cells. Genes Dev 1997;11:72-82.

69 Lofstedt T, Fredlund E, Holmquist-Mengelbier L, Pietras A, Ovenberger M, Poellinger L, Pahlman S: Hypoxia inducible factor-2alpha in cancer. Cell Cycle 2007;6:919-926.

70 Iyer NV, Kotch LE, Agani F, Leung SW, Laughner E, Wenger RH, Gassmann M, Gearhart JD, Lawler AM, Yu AY, Semenza GL: Cellular and developmental control of $\mathrm{O}_{2}$ homeostasis by hypoxia-inducible factor 1 alpha. Genes Dev 1998;12:149-162.

$71 \mathrm{Hu}$ LH, Yang JH, Zhang DT, Zhang S, Wang L, Cai PC, Zheng JF, Huang JS: The TKTL1 gene influences total transketolase activity and cell proliferation in human colon cancer LoVo cells. Anticancer Drugs 2007;18:427433.

$72 \mathrm{Hu}$ CJ, Wang LY, Chodosh LA, Keith B, Simon MC: Differential roles of hypoxia-inducible factor 1alpha (HIF-1alpha) and HIF2alpha in hypoxic gene regulation. Mol Cell Biol 2003;23:9361-9374.

$>73$ Wang V, Davis DA, Haque M, Huang LE, Yarchoan R: Differential gene up-regulation by hypoxia-inducible factor-1alpha and hypoxia-inducible factor-2alpha in HEK293T cells. Cancer Res 2005;65:3299-3306.

74 Grabmaier K, de Weijert MC, Verhaegh GW, Schalken JA, Oosterwijk E: Strict regulation of CAIX(G250/MN) by HIF-1alpha in clear cell renal cell carcinoma. Oncogene 2004;23: 5624-5631.

75 Raval RR, Lau KW, Tran MG, Sowter HM, Mandriota SJ, Li JL, Pugh CW, Maxwell PH, Harris AL, Ratcliffe PJ: Contrasting properties of hypoxia-inducible factor 1 (HIF-1) and HIF-2 in von Hippel-Lindau-associated renal cell carcinoma. Mol Cell Biol 2005;25: 5675-5686.

76 Gunaratnam L, Morley M, Franovic A, de Paulsen N, Mekhail K, Parolin DA, Nakamura E, Lorimer IA, Lee S: Hypoxia inducible factor activates the transforming growth factor-alpha/epidermal growth factor receptor growth stimulatory pathway in $\operatorname{VHL}(-/-)$ renal cell carcinoma cells. J Biol Chem 2003; 278:44966-44974.

77 Makino Y, Cao R, Svensson K, Bertilsson G, Asman M, Tanaka H, Cao Y, Berkenstam A, Poellinger L: Inhibitory PAS domain protein is a negative regulator of hypoxia-inducible gene expression. Nature 2001;414:550-554.
78 Kurihara T, Kubota Y, Ozawa Y, Takubo K, Noda K, Simon MC, Johnson RS, Suematsu M, Tsubota K, Ishida S, Goda N, Suda T, Okano $\mathrm{H}$ : von Hippel-Lindau protein regulates transition from the fetal to the adult circulatory system in retina. Development 2010;137:1563-1571.

79 Ozaki H, Yu AY, Della N, Ozaki K, Luna JD, Yamada H, Hackett SF, Okamoto N, Zack DJ, Semenza GL, Campochiaro PA: Hypoxia inducible factor-1alpha is increased in ischemic retina: temporal and spatial correlation with VEGF expression. Invest Ophthalmol Vis Sci 1999;40:182-189.

80 Caprara C, Thiersch M, Lange C, Joly S, Samardzija M, Grimm C: HIF1A is essential for the development of the intermediate plexus of the retinal vasculature. Invest Ophthalmol Vis Sci 2011;52:2109-2117.

-81 Lange C, Caprara C, Tanimoto N, Beck S, Huber G, Samardzija M, Seeliger M, Grimm $\mathrm{C}$ : Retina-specific activation of a sustained hypoxia-like response leads to severe retinal degeneration and loss of vision. Neurobiol Dis 2011;41:119-130.

82 Hughes JM, Groot AJ, van der Groep P, Sersansie R, Vooijs M, van Diest PJ, Van Noorden CJ, Schlingemann RO, Klaassen I: Active HIF-1 in the normal human retina. J Histochem Cytochem 2010;58:247-254.

$>83$ Kaur C, Sivakumar V, Foulds WS, Luu CD, Ling EA: Cellular and vascular changes in the retina of neonatal rats after an acute exposure to hypoxia. Invest Ophthalmol Vis Sci 2009;50:5364-5374.

84 Mowat FM, Luhmann UF, Smith AJ, Lange C, Duran Y, Harten S, Shukla D, Maxwell PH, Ali RR, Bainbridge JW: HIF-1alpha and HIF-2alpha are differentially activated in distinct cell populations in retinal ischaemia. PLoS ONE 2010;5:e11103.

$\checkmark 85$ Crosson LA, Kroes RA, Moskal JR, Linsenmeier RA: Gene expression patterns in hypoxic and post-hypoxic adult rat retina with special reference to the NMDA receptor and its interactome. Mol Vis 2009;15:296-311.

86 Lin M, Chen Y, Jin J, Hu Y, Zhou KK, Zhu M, Le YZ, Ge J, Johnson RS, Ma JX: Ischaemiainduced retinal neovascularisation and diabetic retinopathy in mice with conditional knockout of hypoxia-inducible factor-1 in retinal Muller cells. Diabetologia 2011;54: 1554-1566.

87 Weidemann A, Krohne TU, Aguilar E, Kurihara T, Takeda N, Dorrell MI, Simon MC, Haase VH, Friedlander M, Johnson RS: Astrocyte hypoxic response is essential for pathological but not developmental angiogenesis of the retina. Glia 2010;58:1177-1185.

88 Li C, Xu Y, Jiang D, Hong W, Guo X, Wang P, Li W: The expression of HIF-1 in the early diabetic NOD mice. Yan Ke Xue Bao 2006; 22:107-111. 
89 Wright WS, McElhatten RM, Messina JE, Harris NR: Hypoxia and the expression of HIF-1alpha and HIF-2alpha in the retina of streptozotocin-injected mice and rats. Exp Eye Res 2010;90:405-412.

90 Wang X, Wang G, Wang Y: Intravitreous vascular endothelial growth factor and hypoxia-inducible factor $1 \mathrm{a}$ in patients with proliferative diabetic retinopathy. Am J Ophthalmol 2009;148:883-889.

-91 Inomata Y, Hirata A, Takahashi E, Kawaji T, Fukushima M, Tanihara H: Elevated erythropoietin in vitreous with ischemic retinal diseases. Neuroreport 2004;15:877879.

-92 Matsunaga N, Chikaraishi Y, Izuta H, Ogata N, Shimazawa M, Matsumura M, Hara $\mathrm{H}$ : Role of soluble vascular endothelial growth factor receptor-1 in the vitreous in proliferative diabetic retinopathy. Ophthalmology 2008;115:1916-1922.

$\checkmark 93$ Kuiper EJ, Van Nieuwenhoven FA, de Smet MD, van Meurs JC, Tanck MW, Oliver N, Klaassen I, Van Noorden CJ, Goldschmeding R, Schlingemann RO: The angio-fibrotic switch of VEGF and CTGF in proliferative diabetic retinopathy. PLoS ONE 2008; 3:e2675.

-94 bu El-Asrar AM, Missotten L, Geboes K: Expression of hypoxia-inducible factor-1alpha and the protein products of its target genes in diabetic fibrovascular epiretinal membranes. Br J Ophthalmol 2007;91:822-826.

$\$ 95$ Lim JI, Spee C, Hinton DR: A comparison of hypoxia-inducible factor-alpha in surgically excised neovascular membranes of patients with diabetes compared with idiopathic epiretinal membranes in nondiabetic patients. Retina 2010;30:1472-1478.

96 Dehne N, Brune B: HIF-1 in the inflammatory microenvironment. Exp Cell Res 2009; 315:1791-1797.

-97 Noma H, Funatsu H, Mimura T, Eguchi S, Shimada K, Hori S: Vitreous levels of pigment epithelium-derived factor and vascular endothelial growth factor in macular edema with central retinal vein occlusion. Curr Eye Res 2011;36:256-263.

-98 Stahl A, Buchwald A, Martin G, Junker B, Chen J, Hansen LL, Agostini HT, Smith LE, Feltgen N: Vitreal levels of erythropoietin are increased in patients with retinal vein occlusion and correlate with vitreal VEGF and the extent of macular edema. Retina 2010;30:1524-1529.

$\$ 99$ Inoue Y, Yanagi Y, Matsuura K, Takahashi H, Tamaki Y, Araie M: Expression of hypoxia-inducible factor lalpha and 2alpha in choroidal neovascular membranes associated with age-related macular degeneration. Br J Ophthalmol 2007;91:1720-1721.

100 Sheridan CM, Pate S, Hiscott P, Wong D, Pattwell DM, Kent D: Expression of hypoxia-inducible factor-1alpha and -2alpha in human choroidal neovascular membranes. Graefes Arch Clin Exp Ophthalmol 2009; 247:1361-1367.
101 Lange CA, Mowat FM, Luhmann UFO, Smith AJ, Maxwell PH, Ali RR, Bainbridge JW: Von Hippel-Lindau expression in the retinal pigment epithelium is essential for normal eye development and vascular homeostasis. ARVO abstract 2010;5973/A194.

102 Frayser R, Gray GW, Houston CS: Control of the retinal circulation at altitude. J Appl Physiol 1974;37:302-304.

103 Papst N, Demant E, Niemeyer G: Changes in $\mathrm{pO}_{2}$ induce retinal autoregulation in vitro. Graefes Arch Clin Exp Ophthalmol 1982;219:6-10

104 Brinchmann-Hansen O, Myhre K, Sandvik $\mathrm{L}$ : Retinal vessel responses to exercise and hypoxia before and after high altitude acclimatisation. Eye (Lond) 1989;3:768-776.

105 Rennie D, Morrissey J: Retinal changes in Himalayan climbers. Arch Ophthalmol 1975;93:395-400.

-106 Kergoat H, Marinier JA, Lovasik JV: Effects of transient mild systemic hypoxia on the pulsatile choroidal blood flow in healthy young human adults. Curr Eye Res 2005;30: 465-470.

107 Bosch MM, Merz TM, Barthelmes D, Petrig BL, Truffer F, Bloch KE, Turk A, Maggiorini M, Hess T, Schoch OD, Hefti U, Sutter FK, Pichler J, Huber A, Landau K: New insights into ocular blood flow at very high altitudes. J Appl Physiol 2009; 106:454-460.

108 Michaelson IC, Herz N, Lewkowitz E, Kertesz D: Effect of increased oxygen on the development of the retinal vessels; an experimental study. Br J Ophthalmol 1954;38: 577-587.

109 Wise GN: Retinal neovascularization. Trans Am Ophthalmol Soc 1956;54:729_ 826.

110 Aiello LP, Avery RL, Arrigg PG, Keyt BA, Jampel HD, Shah ST, Pasquale LR, Thieme H, Iwamoto MA, Park JE: Vascular endothelial growth factor in ocular fluid of patients with diabetic retinopathy and other retinal disorders. N Engl J Med 1994;331: 1480-1487.

111 Holmes DI, Zachary I: The vascular endothelial growth factor (VEGF) family: angiogenic factors in health and disease. Genome Biol 2005;6:209.

112 de Vries C, Escobedo JA, Ueno H, Houck K, Ferrara N, Williams LT: The fms-like tyrosine kinase, a receptor for vascular endothelial growth factor. Science 1992;255: 989-991.

113 Millauer B, Wizigmann-Voos S, Schnurch H, Martinez R, Moller NP, Risau W, Ullrich A: High affinity VEGF binding and developmental expression suggest Flk-1 as a major regulator of vasculogenesis and angiogenesis. Cell 1993;72:835-846.
114 Miller JW, Adamis AP, Shima DT, D’Amore PA, Moulton RS, O'Reilly MS, Folkman J, Dvorak HF, Brown LF, Berse B: Vascular endothelial growth factor/vascular permeability factor is temporally and spatially correlated with ocular angiogenesis in a primate model. Am J Pathol 1994;145:574584.

115 Yancopoulos GD, Davis S, Gale NW, Rudge JS, Wiegand SJ, Holash J: Vascular-specific growth factors and blood vessel formation. Nature 2000;407:242-248.

- 116 Marneros AG, Fan J, Yokoyama Y, Gerber HP, Ferrara N, Crouch RK, Olsen BR: Vascular endothelial growth factor expression in the retinal pigment epithelium is essential for choriocapillaris development and visual function. Am J Pathol 2005; 167: 1451-1459.

117 Zhang P, Wang Y, Hui Y, Hu D, Wang H, Zhou J, Du H: Inhibition of VEGF expression by targeting HIF-1 alpha with small interference RNA in human RPE cells. Ophthalmologica 2007;221:411-417.

118 Liu XL, Li YJ, Liu YZ, Ge J: Effects of human retinal glial cells under hypoxic conditions on circulating endothelial progenitor cells. Zhonghua Yan Ke Za Zhi 2006;42:10891094.

119 Cormier-Regard S, Nguyen SV, Claycomb WC: Adrenomedullin gene expression is developmentally regulated and induced by hypoxia in rat ventricular cardiac myocytes. J Biol Chem 1998;273:17787-17792.

120 Kietzmann T, Roth U, Jungermann K: Induction of the plasminogen activator inhibitor-1 gene expression by mild hypoxia via a hypoxia response element binding the hypoxia-inducible factor-1 in rat hepatocytes. Blood 1999;94:4177-4185.

121 Fuchshofer R, Yu AL, Teng HH, Strauss R, Kampik A, Welge-Lussen U: Hypoxia/reoxygenation induces CTGF and PAI-1 in cultured human retinal pigment epithelium cells. Exp Eye Res 2009;88:889-899.

122 Kitamura K, Kangawa K, Kawamoto M, Ichiki Y, Nakamura S, Matsuo H, Eto T: Adrenomedullin: a novel hypotensive peptide isolated from human pheochromocytoma. Biochem Biophys Res Commun 1993;192: 553-560.

123 Ribatti D, Nico B, Spinazzi R, Vacca A, Nussdorfer GG: The role of adrenomedullin in angiogenesis. Peptides 2005;26:16701675.

124 Udono T, Takahashi K, Nakayama M, Murakami O, Durlu YK, Tamai M, Shibahara $S$ : Adrenomedullin in cultured human retinal pigment epithelial cells. Invest Ophthalmol Vis Sci 2000;41:1962-1970.

125 Zhu Y, Zhang L, Gidday JM: Deferroxamine preconditioning promotes long-lasting retinal ischemic tolerance. J Ocul Pharmacol Ther 2008;24:527-535.

126 Perbal B: CCN proteins: multifunctional signalling regulators. Lancet 2004;363:6264 . 
127 Agirbasli M: Pivotal role of plasminogenactivator inhibitor 1 in vascular disease. Int J Clin Pract 2005;59:102-106.

- 128 Dorrell M, Uusitalo-Jarvinen H, Aguilar E, Friedlander M: Ocular neovascularization: basic mechanisms and therapeutic advances. Surv Ophthalmol 2007;52(suppl 1):S3S19.

129 Hernandez C, Lecube A, Segura RM, Sararols L, Simo R: Nitric oxide and vascular endothelial growth factor concentrations are increased but not related in vitreous fluid of patients with proliferative diabetic retinopathy. Diabet Med 2002;19:655-660.

-130 Cicik E, Tekin H, Akar S, Ekmekci OB, Donma O, Koldas L, Ozkan S: Interleukin-8, nitric oxide and glutathione status in proliferative vitreoretinopathy and proliferative diabetic retinopathy. Ophthalmic Res 2003;35:251-255.

-131 Sennlaub F, Courtois Y, Goureau O: Inducible nitric oxide synthase mediates the change from retinal to vitreal neovascularization in ischemic retinopathy. J Clin Invest 2001;107:717-725.

132 Joyal JS, Sitaras N, Binet F, Rivera JC, Stahl A, Zaniolo K, Shao Z, Polosa A, Zhu T, Hamel D, Djavari M, Kunik D, Honore JC, Picard E, Zabeida A, Varma DR, Hickson G, Mancini J, Klagsbrun M, Costantino S, Beausejour C, Lachapelle P, Smith LE, Chemtob S, Sapieha P: Ischemic neurons prevent vascular regeneration of neural tissue by secreting semaphorin $3 \mathrm{~A}$. Blood 2011;117:6024-6035.

133 Ebert BL, Firth JD, Ratcliffe PJ: Hypoxia and mitochondrial inhibitors regulate expression of glucose transporter-1 via distinct Cis-acting sequences. J Biol Chem 1995;270:29083-29089.

134 Badr GA, Zhang JZ, Tang J, Kern TS, Ismail-Beigi F: Glut1 and glut3 expression, but not capillary density, is increased by cobalt chloride in rat cerebrum and retina. Brain Res Mol Brain Res 1999;64:24-33.

-135 Brahimi-Horn MC, Chiche J, Pouyssegur J: Hypoxia signalling controls metabolic demand. Curr Opin Cell Biol 2007;19:223229.

136 Denko NC: Hypoxia, HIF1 and glucose metabolism in the solid tumour. Nat Rev Cancer 2008;8:705-713.

137 Papandreou I, Cairns RA, Fontana L, Lim AL, Denko NC: HIF-1 mediates adaptation to hypoxia by actively downregulating mitochondrial oxygen consumption. Cell Metab 2006;3:187-197.

- 138 Zhang H, Gao P, Fukuda R, Kumar G, Krishnamachary B, Zeller KI, Dang CV, Semenza GL: HIF-1 inhibits mitochondrial biogenesis and cellular respiration in VHLdeficient renal cell carcinoma by repression of C-MYC activity. Cancer Cell 2007;11: 407-420.
139 Doberstein C, Fineman I, Hovda DA, Martin NA, Keenly L, Becker DP: Metabolic alterations accompany ionic disturbances and cellular swelling during a hypoxic insult to the retina: an in vitro study. Acta Neurochir Suppl (Wien) 1994;60:41-44.

140 Barba I, Garcia-Ramirez M, Hernandez C, Alonso MA, Masmiquel L, Garcia-Dorado D, Simo R: Metabolic fingerprints of proliferative diabetic retinopathy: an ${ }^{1} \mathrm{H}-\mathrm{NMR}$ based metabonomic approach using vitreous humor. Invest Ophthalmol Vis Sci 2010;51:4416-4421.

141 Wang GL, Semenza GL: General involvement of hypoxia-inducible factor 1 in transcriptional response to hypoxia. Proc Natl Acad Sci USA 1993;90:4304-4308.

142 Fandrey J: Oxygen-dependent and tissuespecific regulation of erythropoietin gene expression. Am J Physiol Regul Integr Comp Physiol 2004;286:R977-R988.

143 Garcia-Ramirez M, Hernandez C, Simo R Expression of erythropoietin and its receptor in the human retina: a comparative study of diabetic and nondiabetic subjects. Diabetes Care 2008;31:1189-1194.

144 Grimm C, Wenzel A, Groszer M, Mayser $\mathrm{H}$, Seeliger M, Samardzija M, Bauer C, Gassmann M, Reme CE: HIF-1-induced erythropoietin in the hypoxic retina protects against light-induced retinal degeneration. Nat Med 2002;8:718-724

145 Zhong YS, Liu XH, Cheng Y, Min YJ: Erythropoietin with retrobulbar administration protects retinal ganglion cells from acute elevated intraocular pressure in rats. J Ocul Pharmacol Ther 2008;24:453-459.

146 Li F, Chong ZZ, Maiese K: Erythropoietin on a tightrope: balancing neuronal and vascular protection between intrinsic and extrinsic pathways. Neurosignals 2004;13: 265-289.

147 Sakanaka M, Wen TC, Matsuda S, Masuda S, Morishita E, Nagao M, Sasaki R: In vivo evidence that erythropoietin protects neurons from ischemic damage. Proc Natl Acad Sci USA 1998;95:4635-4640.

148 Junk AK, Mammis A, Savitz SI, Singh M, Roth S, Malhotra S, Rosenbaum PS, Cerami A, Brines M, Rosenbaum DM: Erythropoietin administration protects retinal neurons from acute ischemia-reperfusion injury. Proc Natl Acad Sci USA 2002;99: 10659-10664.

149 Chen J, Connor KM, Aderman CM, Willett KL, Aspegren OP, Smith LE: Suppression of retinal neovascularization by erythropoietin siRNA in a mouse model of proliferative retinopathy. Invest Ophthalmol Vis Sci 2009;50:1329-1335.

150 DeNiro M, Al-Halafi A, Al-Mohanna FH, Alsmadi O, Al-Mohanna FA: Pleiotropic effects of YC-1 selectively inhibit pathological retinal neovascularization and promote physiological revascularization in a mouse model of oxygen-induced retinopathy. Mol Pharmacol 2010;77:348-367.
151 Boscia F: Current approaches to the management of diabetic retinopathy and diabetic macular oedema. Drugs 2010;70: 2171-2200.

152 Rehak M, Wiedemann P: Retinal vein thrombosis: pathogenesis and management. J Thromb Haemost 2010;8:18861894.

153 Chang YH, Chen PL, Tai MC, Chen CH, Lu DW, Chen JT: Hyperbaric oxygen therapy ameliorates the blood-retinal barrier breakdown in diabetic retinopathy. Clin Experiment Ophthalmol 2006;34:584-589.

154 Thompson CR, Gerstman BS, Jacques SL, Rogers ME: Melanin granule model for laser-induced thermal damage in the retina. Bull Math Biol 1996;58:513-553.

155 Roider J, Michaud NA, Flotte TJ, Birngruber R: Response of the retinal pigment epithelium to selective photocoagulation. Arch Ophthalmol 1992;110:1786-1792.

156 Stefansson E: Ocular oxygenation and the treatment of diabetic retinopathy. Surv Ophthalmol 2006;51:364-380.

157 Stefansson E, Hatchell DL, Fisher BL, Sutherland FS, Machemer R: Panretinal photocoagulation and retinal oxygenation in normal and diabetic cats. Am J Ophthalmol 1986;101:657-664.

158 Pournaras CJ, Tsacopoulos M, Strommer K, Gilodi N, Leuenberger PM: Scatter photocoagulation restores tissue hypoxia in experimental vasoproliferative microangiopathy in miniature pigs. Ophthalmology 1990;97:1329-1333.

159 Funatsu H, Wilson CA, Berkowitz BA, Sonkin PL: A comparative study of the effects of argon and diode laser photocoagulation on retinal oxygenation. Graefes Arch Clin Exp Ophthalmol 1997;235:168-175.

-160 Stefansson E, Machemer R, de Juan E Jr, McCuen BW, Peterson J: Retinal oxygenation and laser treatment in patients with diabetic retinopathy. Am J Ophthalmol 1992;113:36-38.

161 Gottfredsdottir MS, Stefansson E, Jonasson F, Gislason I: Retinal vasoconstriction after laser treatment for diabetic macular edema. Am J Ophthalmol 1993;115:64-67.

162 Augustin AJ, Keller A, Koch F, Jurklies B, Dick B: Effect of retinal coagulation status on oxidative metabolite and VEGF in 208 patients with proliferative diabetic retinopathy. Klin Monbl Augenheilkd 2001;218: 89-94.

163 Hoerle S, Poestgens H, Schmidt J, Kroll P: Effect of pars plana vitrectomy for proliferative diabetic vitreoretinopathy on preexisting diabetic maculopathy. Graefes Arch Clin Exp Ophthalmol 2002;240:197201.

164 Blankenship GW, Machemer R: Long-term diabetic vitrectomy results. Report of 10 year follow-up. Ophthalmology 1985;92: 503-506. 
-165 van Meurs JC, Bolt BJ, Mertens DA, Peperkamp E, De WP: Rubeosis of the iris in proliferative vitreoretinopathy. Retina 1996;16:292-295.

-166 Schachat AP, Oyakawa RT, Michels RG, Rice TA: Complications of vitreous surgery for diabetic retinopathy. 2. Postoperative complications. Ophthalmology 1983;90: $522-530$.

-167 Shui YB, Holekamp NM, Kramer BC, Crowley JR, Wilkins MA, Chu F, Malone PE, Mangers SJ, Hou JH, Siegfried CJ, Beebe DC: The gel state of the vitreous and ascorbate-dependent oxygen consumption: relationship to the etiology of nuclear cataracts. Arch Ophthalmol 2009;127:475-482.

168 Stefansson E: Physiology of vitreous surgery. Graefes Arch Clin Exp Ophthalmol 2009;247:147-163.

-169 Arden GB, Wolf JE, Tsang Y: Does dark adaptation exacerbate diabetic retinopathy? Evidence and a linking hypothesis. Vision Res 1998;38:1723-1729.

-170 Arden GB, Gunduz MK, Kurtenbach A, Volker M, Zrenner E, Gunduz SB, Kamis U, Ozturk BT, Okudan S: A preliminary trial to determine whether prevention of dark adaptation affects the course of early diabetic retinopathy. Eye (Lond) 2010;24: 1149-1155.

-171 Martin DF, Maguire MG, Ying GS, Grunwald JE, Fine SL, Jaffe GJ: Ranibizumab and bevacizumab for neovascular age-related macular degeneration. N Engl J Med 2011; 364:1897-1908.

- 172 Avery RL, Pearlman J, Pieramici DJ, Rabena MD, Castellarin AA, Nasir MA, Giust MJ, Wendel R, Patel A: Intravitreal bevacizumab (Avastin) in the treatment of proliferative diabetic retinopathy. Ophthalmology 2006;113:1695-1615.

173 Tolentino M: Systemic and ocular safety of intravitreal anti-VEGF therapies for ocular neovascular disease. Surv Ophthalmol 2011;56:95-113.

-174 Sears JE, Hoppe G, Ebrahem Q, Anand-Apte B: Prolyl hydroxylase inhibition during hyperoxia prevents oxygen-induced retinopathy. Proc Natl Acad Sci USA 2008;105: 19898-19903.

-175 Ren H, Liu NY, Song XF, Ma YS, Zhai XY: A novel specific application of pyruvate protects the mouse retina against white light damage: differential stabilization of HIF- $1 \alpha$ and HIF-2 $\alpha$. Invest Ophthalmol Vis Sci 2011;52:3112-3118.

-176 Yoshida T, Zhang H, Iwase T, Shen J, Semenza GL, Campochiaro PA: Digoxin inhibits retinal ischemia-induced HIF-1alpha expression and ocular neovascularization. FASEB J 2010;24:1759-1767.

-177 Stroka DM, Burkhardt T, Desbaillets I, Wenger RH, Neil DA, Bauer C, Gassmann $\mathrm{M}$, Candinas D: HIF-1 is expressed in normoxic tissue and displays an organ-specific regulation under systemic hypoxia. FASEB J 2001;15:2445-2453.
178 Wiesener MS, Jurgensen JS, Rosenberger C, Scholze CK, Horstrup JH, Warnecke C, Mandriota S, Bechmann I, Frei UA, Pugh CW, Ratcliffe PJ, Bachmann S, Maxwell $\mathrm{PH}$, Eckardt KU: Widespread hypoxia-inducible expression of HIF-2alpha in distinct cell populations of different organs. FASEB J 2003;17:271-273.

179 Zhang C, Wang YS, Wu H, Zhang ZX, Cai Y, Hou HY, Zhao W, Yang XM, Ma JX: Inhibitory efficacy of hypoxia-inducible factor 1alpha short hairpin RNA plasmid DNA-loaded poly (D,L-lactide-co-glycolide) nanoparticles on choroidal neovascularization in a laser-induced rat model. Gene Ther 2010;17:338-351.

180 Akiyama H, Tanaka T, Itakura H, Kanai H, Maeno T, Doi H, Yamazaki M, Takahashi K, Kimura Y, Kishi S, Kurabayashi M: Inhibition of ocular angiogenesis by an adenovirus carrying the human von Hippel-Lindau tumor-suppressor gene in vivo. Invest Ophthalmol Vis Sci 2004;45:1289-1296.

181 Yeo EJ, Chun YS, Cho YS, Kim J, Lee JC, Kim MS, Park JW: YC-1: a potential anticancer drug targeting hypoxia-inducible factor 1. J Natl Cancer Inst 2003;95:516525.

182 Kaur C, Sivakumar V, Foulds WS: Early response of neurons and glial cells to hypoxia in the retina. Invest Ophthalmol Vis Sci 2006;47:1126-1141.

183 Thiersch M, Raffelsberger W, Frigg R, Samardzija M, Wenzel A, Poch O, Grimm C: Analysis of the retinal gene expression profile after hypoxic preconditioning identifies candidate genes for neuroprotection. BMC Genomics 2008;9:73.

184 Kaur C, Sivakumar V, Foulds WS, Luu CD, Ling EA: Cellular and vascular changes in the retina of neonatal rats after an acute exposure to hypoxia. Invest Ophthalmol Vis Sci 2009;50:5364-5374.

185 Sivakumar V, Zhang Y, Ling EA, Foulds WS, Kaur C: Insulin-like growth factors, angiopoietin-2, and pigment epitheliumderived growth factor in the hypoxic retina. J Neurosci Res 2008;86:702-711.

-186 Sivakumar V, Foulds WS, Luu CD, Ling EA, Kaur C: Retinal ganglion cell death is induced by microglia derived pro-inflammatory cytokines in the hypoxic neonatal retina. J Pathol 2011;224:245-260.

187 Palmer LA, Semenza GL, Stoler MH, Johns RA: Hypoxia induces type II NOS gene expression in pulmonary artery endothelial cells via HIF-1. Am J Physiol 1998;274:L212L219.

188 Eckhart AD, Yang N, Xin X, Faber JE: Characterization of the alpha1B-adrenergic receptor gene promoter region and hypoxia regulatory elements in vascular smooth muscle. Proc Natl Acad Sci USA 1997;94:9487-9492.
$189 \mathrm{Hu}$ J, Discher DJ, Bishopric NH, Webster KA: Hypoxia regulates expression of the endothelin-1 gene through a proximal hypoxia-inducible factor- 1 binding site on the antisense strand. Biochem Biophys Res Commun 1998;245:894-899.

190 Millhorn DE, Raymond R, Conforti L, Zhu W, Beitner-Johnson D, Filisko T, Genter MB, Kobayashi S, Peng M: Regulation of gene expression for tyrosine hydroxylase in oxygen sensitive cells by hypoxia. Kidney Int 1997;51:527-535.

191 Chun YS, Hyun JY, Kwak YG, Kim IS, Kim $\mathrm{CH}$, Choi E, Kim MS, Park JW: Hypoxic activation of the atrial natriuretic peptide gene promoter through direct and indirect actions of hypoxia-inducible factor-1. Biochem J 2003;370:149-157.

192 Gerber HP, Condorelli F, Park J, Ferrara N: Differential transcriptional regulation of the two vascular endothelial growth factor receptor genes. Flt-1, but not Flk-1/KDR, is up-regulated by hypoxia. J Biol Chem 1997; 272:23659-23667.

193 Ronkainen VP, Ronkainen JJ, Hanninen SL, Leskinen H, Ruas JL, Pereira T, Poellinger L, Vuolteenaho O, Tavi P: Hypoxia inducible factor regulates the cardiac expression and secretion of apelin. FASEB J 2007;21:1821-1830.

194 Higgins DF, Biju MP, Akai Y, Wutz A, Johnson RS, Haase VH: Hypoxic induction of Ctgf is directly mediated by Hif-1. Am J Physiol Renal Physiol 2004;287:F1223F1232.

195 Rolfs A, Kvietikova I, Gassmann M, Wenger $\mathrm{RH}$ : Oxygen-regulated transferrin expression is mediated by hypoxia-inducible factor-1. J Biol Chem 1997;272:20055-20062.

196 Tacchini L, Bianchi L, Bernelli-Zazzera A, Cairo G: Transferrin receptor induction by hypoxia. HIF-1-mediated transcriptional activation and cell-specific post-transcriptional regulation. J Biol Chem 1999;274: 24142-24146.

197 Mukhopadhyay CK, Mazumder B, Fox PL: Role of hypoxia-inducible factor-1 in transcriptional activation of ceruloplasmin by iron deficiency. J Biol Chem 2000;275: 21048-21054.

198 Wang D, Wang LH, Zhao Y, Lu YP, Zhu L: Hypoxia regulates the ferrous iron uptake and reactive oxygen species level via divalent metal transporter 1 (DMT1) Exon1B by hypoxia-inducible factor-1. IUBMB Life 2010;62:629-636.

199 Carmeliet P, Dor Y, Herbert JM, Fukumura D, Brusselmans K, Dewerchin M, Neeman M, Bono F, Abramovitch R, Maxwell P, Koch CJ, Ratcliffe P, Moons L, Jain RK, Collen D, Keshert E: Role of HIF-1alpha in hypoxia-mediated apoptosis, cell proliferation and tumour angiogenesis. Nature 1998;394:485-490. 
-200 Feldser D, Agani F, Iyer NV, Pak B, Ferreira G, Semenza GL: Reciprocal positive regulation of hypoxia-inducible factor lalpha and insulin-like growth factor 2. Cancer Res 1999;59:3915-3918.

-201 Tazuke SI, Mazure NM, Sugawara J, Carland G, Faessen GH, Suen LF, Irwin JC, Powell DR, Giaccia AJ, Giudice LC: Hypoxia stimulates insulin-like growth factor binding protein 1 (IGFBP-1) gene expression in HepG2 cells: a possible model for IGFBP-1 expression in fetal hypoxia. Proc Natl Acad Sci USA 1998;95:10188-10193.

-202 Sanchez-Elsner T, Botella LM, Velasco B, Langa C, Bernabeu C: Endoglin expression is regulated by transcriptional cooperation between the hypoxia and transforming growth factor-beta pathways. J Biol Chem 2002;277:43799-43808

-203 Wagner KD, Wagner N, Wellmann S, Schley G, Bondke A, Theres H, Scholz H: Oxygen-regulated expression of the Wilms' tumor suppressor Wt1 involves hypoxiainducible factor-1 (HIF-1). FASEB J 2003; 17:1364-1366.

-204 Mazure NM, Chauvet C, Bois-Joyeux B, Bernard MA, Nacer-Cherif H, Danan JL: Repression of alpha-fetoprotein gene expression under hypoxic conditions in human hepatoma cells: characterization of a negative hypoxia response element that mediates opposite effects of hypoxia inducible factor-1 and c-Myc. Cancer Res 2002; 62:1158-1165.

205 Nikitenko LL, Smith DM, Bicknell R, Rees MC: Transcriptional regulation of the CRLR gene in human microvascular endothelial cells by hypoxia. FASEB J 2003;17: 1499-1501.

206 Bruick RK: Expression of the gene encoding the proapoptotic Nip3 protein is induced by hypoxia. Proc Natl Acad Sci USA 2000;97:9082-9087.
207 An WG, Kanekal M, Simon MC, Maltepe E, Blagosklonny MV, Neckers LM: Stabilization of wild-type p53 by hypoxia-inducible factor 1alpha. Nature 1998;392:405-408.

208 Staller P, Sulitkova J, Lisztwan J, Moch H, Oakeley EJ, Krek W: Chemokine receptor CXCR4 downregulated by von Hippel-Lindau tumour suppressor pVHL. Nature 2003;425:307-311.

209 Takahashi Y, Takahashi S, Shiga Y, Yoshimi T, Miura T: Hypoxic induction of prolyl 4-hydroxylase alpha (I) in cultured cells. J Biol Chem 2000;275:14139-14146.

210 Semenza GL, Roth PH, Fang HM, Wang GL: Transcriptional regulation of genes encoding glycolytic enzymes by hypoxia-inducible factor 1. J Biol Chem 1994;269: 23757-23763.

-211 Lofstedt T, Fredlund E, Noguera R, Navarro S, Holmquist-Mengelbier L, Beckman S, Pahlman S, Axelson H: HIF-1alpha induces MXI1 by alternate promoter usage in human neuroblastoma cells. Exp Cell Res 2009;315:1924-1936.

-212 Kim JW, Tchernyshyov I, Semenza GL, Dang CV: HIF-1-mediated expression of pyruvate dehydrogenase kinase: a metabolic switch required for cellular adaptation to hypoxia. Cell Metab 2006;3:177-185.

213 Ullah MS, Davies AJ, Halestrap AP: The plasma membrane lactate transporter MCT4, but not MCT1, is up-regulated by hypoxia through a HIF-1alpha-dependent mechanism. J Biol Chem 2006;281:90309037.

214 Fukuda R, Zhang H, Kim JW, Shimoda L, Dang CV, Semenza GL: HIF-1 regulates cytochrome oxidase subunits to optimize efficiency of respiration in hypoxic cells. Cell 2007;129:111-122.

215 Graven KK, Yu Q, Pan D, Roncarati JS, Farber HW: Identification of an oxygen responsive enhancer element in the glyceraldehyde-3-phosphate dehydrogenase gene. Biochim Biophys Acta 1999;1447:208-218.
216 Minchenko O, Opentanova I, Caro J: Hypoxic regulation of the 6 -phosphofructo-2kinase/fructose-2,6-bisphosphatase gene family (PFKFB-1-4) expression in vivo. FEBS Lett 2003;554:264-270.

217 Schaffer L, Scheid A, Spielmann P, Breymann C, Zimmermann R, Meuli M, Gassmann M, Marti HH, Wenger RH: Oxygen-regulated expression of TGF-beta 3, a growth factor involved in trophoblast differentiation. Placenta 2003;24:941-950.

-218 Lee PJ, Jiang BH, Chin BY, Iyer NV, Alam J, Semenza GL, Choi AM: Hypoxia-inducible factor-1 mediates transcriptional activation of the heme oxygenase-1 gene in response to hypoxia. J Biol Chem 1997;272: 5375-5381.

219 O’Rourke JF, Pugh CW, Bartlett SM, Ratcliffe PJ: Identification of hypoxically inducible mRNAs in HeLa cells using differential-display PCR. Role of hypoxia-inducible factor-1. Eur J Biochem 1996;241: 403-410.

$>220$ Kaluz S, Kaluzova M, Chrastina A, Olive PL, Pastorekova S, Pastorek J, Lerman MI, Stanbridge EJ: Lowered oxygen tension induces expression of the hypoxia marker $\mathrm{MN} /$ carbonic anhydrase IX in the absence of hypoxia-inducible factor 1 alpha stabilization: a role for phosphatidylinositol 3'-kinase. Cancer Res 2002;62:4469-4477.

-221 Grosfeld A, Andre J, Hauguel-De MS, Berra E, Pouyssegur J, Guerre-Millo M: Hypoxiainducible factor 1 transactivates the human leptin gene promoter. J Biol Chem 2002; 277:42953-42957.

222 Hackenbeck T, Huber R, Schietke R, Knaup KX, Monti J, Wu X, Klanke B, Frey B, Gaipl U, Wullich B, Ferbus D, Goubin G, Warnecke C, Eckardt KU, Wiesener MS: The GTPase RAB20 is a HIF target with mitochondrial localization mediating apoptosis in hypoxia. Biochim Biophys Acta 2011; 1813:1-13. 